\title{
Geocryological and Hydrogeological Conditions of the Western Part of Nordenskiold Land (Spitsbergen Archipelago)
}

\author{
N. E. Demidov ${ }^{a}$ *, A. L. Borisik ${ }^{a}$, S. R. Verkulich ${ }^{a}$, S. Wetterich ${ }^{b}$, A. Yu. Gunar ${ }^{c}$, V. E. Demidov ${ }^{a}$, \\ N. V. Zheltenkova ${ }^{c}$, A. V. Koshurnikov ${ }^{c}$, V. M. Mikhailova ${ }^{a}$, A. L. Nikulina ${ }^{a}$, A. L. Novikov ${ }^{a}$, \\ L. M. Savatyugin ${ }^{a}$, A. N. Sirotkin ${ }^{d}$, A. V. Terekhov ${ }^{a}$, Yu. V. Ugrumov ${ }^{a}$, and L. Schirrmeister ${ }^{b}$ \\ ${ }^{a}$ State Research Center "Arctic and Antarctic Research Institute", St. Petersburg, 199397 Russia \\ ${ }^{b}$ Helmholtz Center for Polar and Marine Research, Alfred Wegener Institute, Potsdam, 14473 Germany \\ ${ }^{c}$ Faculty of Geology, Moscow State University, Moscow, 19991 Russia \\ ${ }^{d}$ Polar Marine Geological Exploration Expedition, Lomonosov, 198412 Russia \\ *e-mail:nikdemidov@mail.ru \\ Received August 31, 2020; revised September 15, 2020; accepted September 16, 2020
}

\begin{abstract}
This work summarizes the archived data of geocryological and hydrogeological conditions in the west of Nordenskiold Land on the Spitsbergen Archipelago. The historical data obtained in the Soviet period during coal exploration are reviewed together with the results of our own studies performed as part of the Russian Scientific Arctic Expedition on Spitsbergen (RAE-S) in 2016-2020. With respect to geocryology, the region is assigned to the zone of continuous permafrost. The thickness of rocks and sediments with temperatures below zero is about $100 \mathrm{~m}$ near the coast and increases to $540 \mathrm{~m}$ on watersheds. The mean annual ground temperature near the zero-amplitude depth varies from -3.6 to $-2.2^{\circ} \mathrm{C}$. Below this layer, the temperature curve in the top part of the section tends to deviate toward positive temperatures, reflecting the modern cycle of climate warming. From the hydrogeological point of view, the area belongs to the marginal zone of the West Spitsbergen cryoadartesian basin. Seawater intrusions near the coast form saline subpermafrost aquifers, including those with temperatures below zero, reflecting the seawater (sodium chloride) composition and hydraulic heads close to sea level. Fresh and slightly saline (sodium bicarbonate on the east coast of Grønfjorden and magnesium-calcium sulfate in gypsum-bearing deposits on the west coast) subpermafrost water with hydraulic heads reaching $100 \mathrm{~m}$ above sea level is fed by water-saturated ice in the deep layers of large glaciers.
\end{abstract}

Keywords: Spitsbergen, permafrost, temperature monitoring borehole, EM sounding, GPR, cryogenic structure, pingo, subpermafrost water, warm-based glaciers, West Spitsbergen cryoadartesian basin

DOI: $10.1134 / \mathrm{S} 000143382011002 \mathrm{X}$

\section{INTRODUCTION}

The Spitsbergen Archipelago is the first of the Arctic archipelagos of Eurasia located in the way of western air masses and is characterized by intensively developing processes of cryosphere degradation due to climate warming. Like other areas of the cryolithozone, the study of the dynamics of permafrost on Spitsbergen is not only a scientific task related to its impact on landscapes, hydrosphere, and biogeochemical cycles of greenhouse gases; it is also an applied problem, because permafrost affects the stability of the foundations of constructions, water flows to mines, water supply aspects, etc. This article is devoted to the main features of the permafrost-hydrogeological conditions in the west of the Nordenskiold Land, where Russian (formerly Soviet) mines and the settlements of Barentsburg, Kolsbey, and Grumant are located. In recent years, the Russian Scientific Center on Spitsbergen has been comprehensively monitoring the archipelago cryosphere.

This research area is one of the most interesting regions of the high-latitude Arctic, and its permafrost-hydrogeological conditions are the most comprehensively studied. In 1912, a Russian expedition under the leadership by V.A. Rusanov revealed a vast coal-bearing area and installed pegs on the Grumant field, where coal mining began the next year. In 1932, the Arktikugol enterprise was founded and began performing all works related to the study and exploitation of coal deposits belonging to the USSR by the order of the Soviet Government. The Barentsburg field was purchased from a Dutch mining company Nederlandsche Spitsbergen Compagnie (NESPICO). Since that time, the Soviet Union performed large-scale prospecting and exploration work for coal there, including exploratory drilling and drilling of specialized hydrogeological wells to assess water flows to mines (Rossi- 
iskie..., 1998). By 1976, the drilling volume reached 80400 lineal meters, and the contract areas were covered by a network of wells with a distance between them of at least $250 \mathrm{~m}$. In 1975, the Grumant parametric well of a depth of $3173 \mathrm{~m}$ was drilled in the settlement of Kolsbey, using the Leonid Krasin icebreaker as a residential and energy base. Its aim was to assess the oil and gas potential and obtain reference data on the geology, hydrogeology, and geophysics of the West Spitsbergen trough and the surrounding shelf (Gramberg et al., 1985). Frozen rocks and groundwater were also studied as a part of engineering-geological surveys for the construction of mine infrastructure and settlements and for revealing sources of water supply (Kasatkin and Neizvestnov, 1983; Kurkov and Neizvestnov, 1983; Misnik and Belousov, 1983). The main works were performed by the Spitsbergen party of the Sevmorgeologiya Industrial Geological Association by the order of Arktikugol.

The first Soviet weather station on the archipelago was established at the Grumant mine in 1932 and was moved to Barentsburg in 1933 (WMO index 20107). Meteorological and marine hydrological observations at this station were only interrupted during World War II (Antsiferova, 2020). Prior to it, the Green Harbour Norwegian Weather Station (WMO index 99821), the oldest one on Spitsbergen, functioned on Cape Finneset from 1911 to 1930 . It was located only $2 \mathrm{~km}$ from the modern weather station in Barentsburg (Forland et al., 1997). Data from these two weather stations make it possible to assess trends in the air temperature variation in the study area over a period of more than 100 years.

Similarly to the entire archipelago, the studied area is characterized by land glaciation, which determines specific permafrost-hydrogeological conditions. Research on Spitsbergen by the Soviet Glaciological Expedition of the Institute of Geography of the Academy of Sciences of the Soviet Union began in 1965 (Glyatsiologiya..., 1985). B.I. Vtyurin, a member of the glaciological expedition, studied the cryogenic structure of Quaternary rocks in outcrops and pits in 1987-1988 (Vtyurin, 1989, 1990).

It should be pointed out that the works by B.I. Vtyurin (1989, 1990) and N.I. Obidin (1958) and the Hydrogeology, Engineering Geology, and Geomorphology of the Svalbard Archipelago collection of articles (1983) are some of few published academic works of the Soviet period devoted to permafrost and groundwater in the area of mines on Spitsbergen. Most of the works are reports of departments. They are little known in Russia and are not known abroad. For example, the article by Norwegian researchers, which generalizes the history of permafrost study of the Spitsbergen Archipelago (Humlum et al., 2003), does not contain any references to the works of Russian (Soviet) authors.

Research into permafrost started again in Barentsburg in 2016 as part of works of the RAE-S of the Arctic and Antarctic Research Institute (AARI) (Demidov et al., 2016, 2019; Demidov, V.E. and Demidov, N.E., 2019). They included the creation of a network of wells to monitor the temperature of frozen rocks according to the Global Terrestrial Network for Permafrost (GTN-P) (Biskaborn et al., 2019), the study of their cryogenic structure and salinity, monitoring the seasonally thawing layer (STL) according to the Circumpolar Active-Layer Monitoring (CALM) program (Brown et al., 2000; Nelson et al., 2004), researching the internal structure of heaving mounds and other cryogenic phenomena, electrical explorations to map taliks and georadar studies of glaciers to isolate warm ice and subglacial taliks, and the study of the chemical composition of springs and icings.

The aim of this work is to summarize data on the geocryological and hydrogeological conditions of Barentsburg, Kolsbey, and Grumant, including new ones and those obtained in the Soviet period, and to make them available to the scientific community in order to form the basis for further studying and monitoring of the underground cryosphere in this region of Spitsbergen.

\section{STUDY AREA}

Orohydrography. The studied area is located on the Nordenskiold Land (Lotsiya..., 2001) on the western coast of West Spitsbergen, which is a part of the Spitsbergen Group of Islands (Archipelago) (the old Russian name is Grumant, and the old Scandinavian and modern Norwegian name of the Spitsbergen Islands, together with Medvezhii Island, is Svalbard). The western coast of West Spitsbergen, washed by waters of the Greenland Sea, is characterized by a large number of narrow, branched, and mostly deep fiords which extend far into the land. The three settlements and mines are located on the southern coast of Isfjorden, in its bays and fjords: Barentsburg on the eastern shore of Grønfjorden, Kolsbey on the eastern shore of the Coles Bay, and Grumant on the shore of Isfjorden $4.5 \mathrm{~km}$ to the northeast of the Rusanova Cape (Fig. 1). Mountain ranges to the west of Grønfjorden formed by sharply folded rocks stretch in the meridional direction. Gently sloping bedrocks to the east of Grønfjorden look like mountains, because they are deeply dissected by an erosion network. Grendalen, Hollendar, and Coles are the most extensive valleys. Mountain peaks reach $900 \mathrm{~m}$ in altitude.

The climate of the region is strongly affected by the warm West Spitsbergen Current and warm and humid air masses from the Atlantic Ocean. Therefore, the air temperature here is higher than would be expected for these Arctic latitudes. The polar day in Barentsburg lasts 125 days, and the polar night is 112 days (Obidin, 1958). The air temperature may sharply fluctuate in any month between negative and positive values.

The mean, maximal, and minimal annual temperatures over the period from 1912 to 2018 are given 


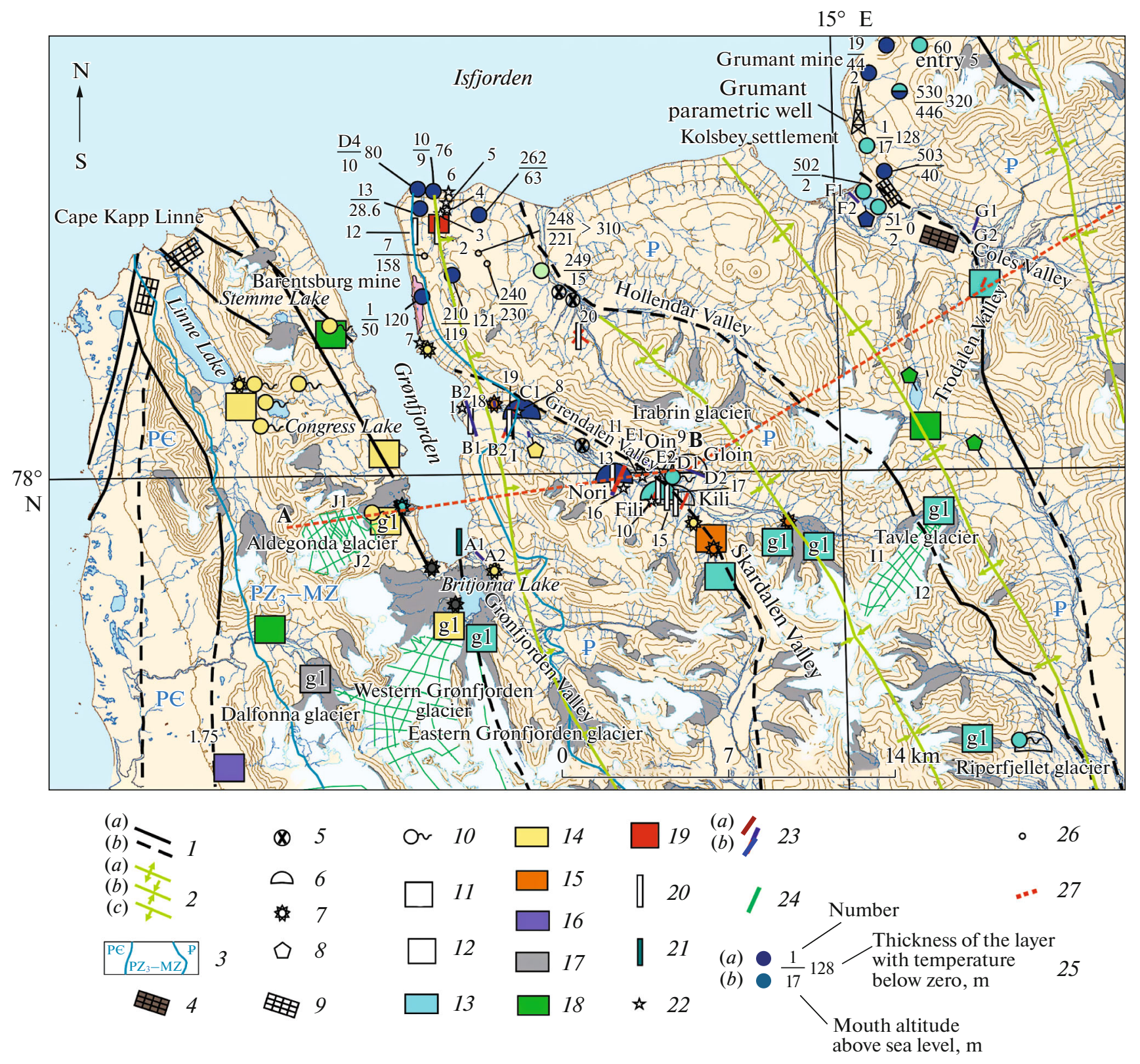

Fig. 1. Map of the actual material used in the article. (1) Faults: identified (a) and assumed (b); (2) main plicative structures of the Paleogene complex: elevations $(a)$, depressions $(b)$, and monoclines $(c)$; (3) areas of geological complexes of different ages: Precambrian (PC), Upper Paleozoic-Mesozoic (PZ $-\mathrm{MZ}$ ), and Paleogene (P); (4) wedge ice; (5) thermokarst craters (according to data of 2019); (6) long-term heaving mounds; (7) ice mounds (blisters); ( 8 ) lake waters; (9) ground polygons; (10) sources; (11) icings near glaciers; and (12) icings of underground waters of deep and shallow runoff. For springs, lakes, ice of heaving mounds, and waters feeding ice and ice mounds, the tints in the map correspond to the following dominating ions in $\mathrm{mg} / \mathrm{L}$ (data of RAE-S, 2019-2020): (13) $\mathrm{HCO}_{3}^{-}$and $\mathrm{Na}^{+}$; (14) $\mathrm{SO}_{4}^{2-}$ and $\mathrm{Ca}^{2+}$; (15) $\mathrm{SO}_{4}^{2-}$ and $\mathrm{Mg}^{2+}$; (16) $\mathrm{HCO}_{3}^{-}$and $\mathrm{Mg}^{2+}$; (17) $\mathrm{HCO}_{3}^{-}$ and $\mathrm{Ca}^{2+} ;(18) \mathrm{SO}_{4}^{2-}$ and $\mathrm{Na}^{+} ;(19)$ the CALM plot with automatic meteorological complex (RAE-S, 2016-2020); (20) stationary thermometric wells (RAE-S, 2016-2020); (21) towed sensor at the bottom of the fjord (RAE-S, 2019-2020); (22) wells with single thermometric measurements (RAE-S, 2016-2020); (23) profiles of EM sounding (RAE-S, 2019): (a) areas without conductors in the section and $(b)$ areas with conductors; (24) GPR profiles (RAE-S, 2018-2020); (25) coal exploration and hydrogeological wells (1932-1986). The waters that are revealed are $(a)$ saline sodium chloride and $(b)$ sodium bicarbonate; (26) wells without data on aquifers (1932-1986); and (27) line of permafrost-hydrogeological section (Fig. 12). 

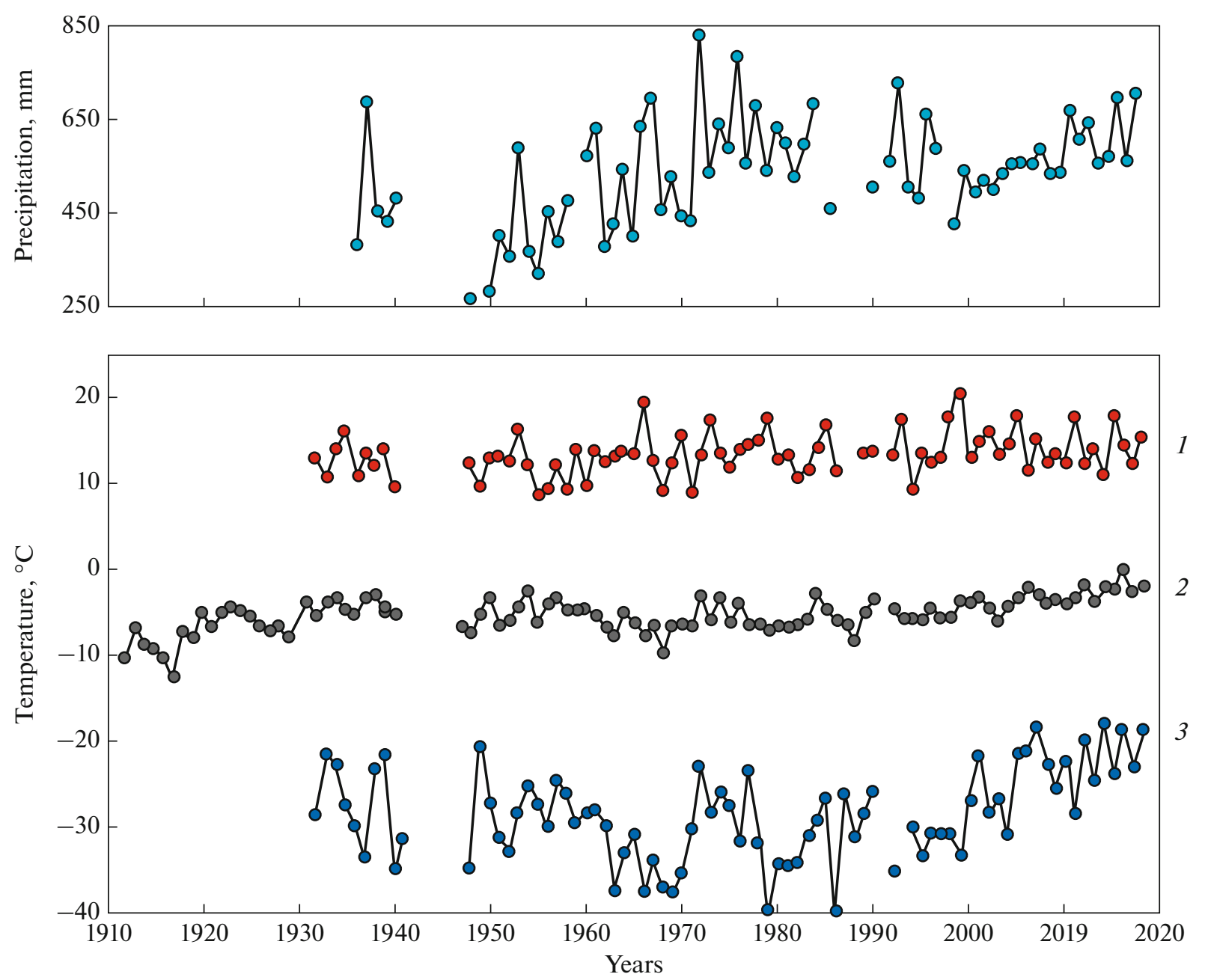

Fig. 2. Changes in precipitation and air temperature by data of meteorological observations in Barentsburg: 1912-1931 are from the Green Harbor Weather Station; 1932-2018 are from the Barentsburg Observatory. (1-3) Temperature: (1) maximal, (2) mean annual, and (3) minimal.

in Fig. 2. The coefficients of the linear trend of anomalies of the mean annual air temperature calculated for 1976-2015 show that the rate of the rise in the mean annual air temperature is $0.92^{\circ} \mathrm{C}$ per 10 years, which is 1.5 times higher than on the Kola Peninsula and twice as high as the mean for the area of Russia (Antsiferova, 2020).

According to data of the Barentsburg weather station, there is also an increase in the precipitation amount (Fig. 2). For example, annual precipitation was $482 \mathrm{~mm}$ in 1940 and $704 \mathrm{~mm}$ in 2018. The precipitation is the greatest from October to March: in the period of particularly high cyclonic activity. The least precipitation occurs from April to July, dominated by stable anticyclonic weather. In general, the precipitation amount in winter is 1.5-2 times higher than in summer (Antsiferova, 2020).

According to data of the 65-year-long observation period (Lotsiya..., 2001), the mean date of coastal ice formation in Barentsburg is January 26, and the mean date of its fracturing is May 5. In 2016-2019, we recorded coastal ice formation only at the head of Grønfjorden, and most of it remained ice-free all year round. In 2020, the coast ice in front of Barentsburg was formed in January and melted in April.

Hydrology. Hydrological works in the studied area were performed according to the order of Arktikugol since the 1930s (Rossiiskie..., 1998) and by the Spitsbergen Glaciological Expedition of the Institute of Geography, Academy of Sciences of the Soviet Union, in 1976-1990 (Oledenenie..., 1975). At the present time, regular hydrological studies are a branch of works of the RAE-S (Romashova et al., 2019).

The Coles, Gren, and Hollendar are the largest rivers, more than $20 \mathrm{~km}$ long with an annual discharge of about 40 million $\mathrm{m}^{3}$. They have two periods of nourishment: spring, when snow melts, and summerautumn, when rivers are fed by water of the STL and rain and melt glacial water. The portion of glacial run- 
off varies from $20-25 \%$ in the Gren River to $50 \%$ in the Aldegonda and Grønfjorden rivers and to $90 \%$ in the Bretjorna River (Romashova et al., 2019). The constant discharge of rivers lasts about 5 months and usually ends by the beginning of October. More than $90 \%$ of river discharge occurs in the 3 summer months (Tret'yakov, 2010). In winter, the rivers freeze to the bottom, except for the Congress River, which is fed by groundwater all year round.

There are several large lakes and many small ones of various origins in the studied area. Valley lakes (Linne, Grendal, and Fara) were formed in the Holocene after the sea regression from the fjords, and some of them may be of thermokarst origin. The Stemme mountain lake, fed by glacial waters, is a source of water supply for the settlement of Barentsburg. Congress Lake, located nearby on a mountain saddle, is of glacial-karst origin. To the north of Linne Lake, a group of small karst lakes is allocated to the outcrop of Permian limestone on the Vardeborgsletta Plain (Salvigsen and Elgersma, 1985). Many small thermokarst lakes are formed on the surface of moraines of retreating glaciers. Large Lake Bretjorna fills an exaration basin in front of the moraine of the Western Grønfjorden glacier. The altitude of the lakes does not exceed $100 \mathrm{~m}$ above sea level, and only the water edge of Ishjern Lake, located on the mountain saddle, has an altitude of $239 \mathrm{~m}$.

The landscapes of the region are diverse: from those of watershed peaks to the landscapes of valleys, glacial moraines, and coastal plains. Peaks, mountain slopes, and moraines are covered by primary and desert-arctic soils with thin herbaceous-moss-lichen groups. Valleys and sea terraces are occupied by typical arctic and arctic-tundra soils under sparse willow-forbs-moss groups (Belousov et al., 1983).

Glaciers. Large mountain-valley and twinned glaciers (Fritjof, West and East Grønfjorden, Aldegonda, Dalfonna, Linne, Wering, etc.) are located on the western shore of Grønfjorden in the region of relatively high submeridional ridges, which catch moisture from the Atlantic. To the east of Grønfjorden, mountain ranges are mainly free of glaciers. Small hanging and mountain-valley glaciers are only preserved in the upper reaches of the Grendalen, Hollendar, and Coles valleys (Tavle, Tunge, Pass, and Ira are the largest of them).

The glaciers of the region are relatively comprehensively studied due to the small distance from the settlement of Barentsburg (Glyatsiologiya..., 1985; Vasilenko et al., 2001; Lavrent'ev, 2008; Romashova et al., 2019; Terekhov et al., 2020). Some large glaciers are characterized by a two-layer structure (Glyatsiologiya..., 1985). The top layer of ice is located in the zone of negative temperatures, while ice below the boundary of $50-100 \mathrm{~m}$ is at the melting point and contains water. The degradation of glaciers is widespread in the west of the Nordenskiold Land during the current 100-year period as a result of climate warming (Mavlyudov et al., 2012). From 1936 to 2017, the area of glaciers decreased on average by $49.5 \%$, and their outer edge retreated by several kilometers (Chernov and Murav'ev, 2018). Intraglacial channels are described in a number of glaciers: water through them is drained to bed rocks (Mavlyudov, 2007).

Geology. The studied area is allocated to the contact zone of two large structures of the first order (Krasil'shchikov, 1973): the horst-anticlinorium of the western coast of Spitsbergen and the West Spitsbergen grabenlike trough. The contact zone of these two structures is represented by the western boundary fault zone (Livshits, 1973) covered by waters of Grønfjorden and the Fritjof and Western and Eastern Grønfjorden glaciers.

To the east and southeast of Grønfjorden, the structures of the West Spitsbergen graben-like trough are composed of Lower Cretaceous and Paleogene sedimentary rocks, which are subhorizontal or gently sloping and are represented by sequences of alternating sandstones, siltstones, and argillites; the Paleogene deposits also contain layers and lenses of coal and bentonite clays. Cretaceous deposits outcrop only in a small area of the coastal part of Grønfjorden and Isfjorden. In the area of the Barentsburg mine, rock strata are inclined to the east-northeast at an angle of $10-12^{\circ}$ (Cretaceous rocks) and $5^{\circ}-8^{\circ}$ (Paleogene rocks). At the Grumant mine, Cretaceous and Paleogene rocks are characterized by the inclination to the west-southwest at angles reaching $5^{\circ}-8^{\circ}$. According to A.I. Panov et al. (cited by (Rossiiskie..., 1998)), such an inclination of layers is the result of a modification of the western part of the West Spitsbergen trough by a number of disjunctive and plicative structures, such as the Hollendardalen and Coles Bay faults or the Iradalen trough, which are characterized by a submeridional direction; the fault amplitudes do not exceed 100-150 m.

The geological structure of the western coast of Grønfjorden is more complicated (Sirotkin et al., 2017). Ancient rocks-structures of the horst-anticlinorium of the western coast of Spitsbergen-outcrop here. Precambrian (Mid-Riphean-Vendian) rocks are metamorphosed and are represented by mica-chlorite shale, marbles, quartzites, metabasites, and metatillites. The Upper Paleozoic-Mesozoic sedimentary rocks are composed of siltstones, argillites, and sandstones, which are typical for the entire studied area, and they are accompanied by limestone, dolomites, gypsum, and phosphorites. All the rocks are represented by interrelated folds with an inclination of $20^{\circ}-90^{\circ}$ on the wings. They are transformed by a system of faults, as well as dikes and sills of Mesozoic dolerites.

Quaternary deposits are represented by colluvial, proluvial, eluvial-deluvial, alluvial, fluvioglacial, and glacial deposits typical for mountainous countries, as well as by marine rocks. The cover of Quaternary deposits, except for the STL and areas of taliks, is often completely frozen. Some features of its structure are discussed in more detail below. 


\section{METHODS OF RESEARCH}

The following equipment and approaches were used for implementing works according to the RAE-S project in 2016-2020.

Boreholes were dry-drilled by an UKB-12/25 small-sized rig (Vorovskii machine-building plant, Yekaterinburg, Russia) without blowing. The total volume of drilling was $156 \mathrm{~m}$ with a maximum depth of $25 \mathrm{~m}$. The drilling was accompanied by photographs of the cores, by a description of the lithology and cryogenic structure, and by sampling. Hydrochemical analysis of ice (73 samples) and water samples (93 samples) was performed at a RAE-S chemical-analytical laboratory in Barentsburg. We also determined the weight humidity (116 samples) and chemical composition of water extract (195 samples) from samples of frozen rocks $(20 \mathrm{~g}$ of dry weighted sample to $100 \mathrm{~mL}$ of distilled $\mathrm{H}_{2} \mathrm{O}$ ). Granulometric analyses ( 173 samples) were performed at the laboratory of the Alfred Wegener Institute (Potsdam, Germany) using a Malvern Mastersizer 3000 laser-diffraction particle size analyzer (Great Britain); the GRADISTAT program was used for data interpretation (Blott and Pye, 2001). Geo Precision (Germany) and MGU-Geofizika (Russia) thermistor chains were used to measure the temperature in wells. The thickness of the STL was measured at the end of the thawing period by a metal probe according to standards of the CALM program.

Electromagnetic (EM) sounding was performed by time domain method using Tem-Fast equipment (AEMR, Ltd., the Netherlands) in a single-loop version. A square loop of copper wire $(25 \times 25,50 \times 50$, or $100 \times 100 \mathrm{~m}$ ) was used as the radiating and receiving antenna. In general, we analyzed 237 NTES pegs with a current of 1 and $4 \mathrm{~A}$, including 15 profiles of a total length of about $9 \mathrm{~km}$.

Georadar surveys on the glaciers were performed by a pulseEKKO PRO GPR (Sensors\&Software, Canada) in combination with the Sokkia GRX2 dual-frequency GPS/GLONASS positioning system (Sokkia Topcon Co, Japan). During the observation, a 50-MHz dipole antenna set on a special sled was dragged behind a snowmobile at a speed of 5-10 km/h. Horizontal and altitudinal coordinates of each analyzed site were determined with high accuracy simultaneously with the recording of geophysical information. The total length of georadar profiles was about $160 \mathrm{~km}$.

Aerial photography of heaving mounds was performed from a height less than $120 \mathrm{~m}$ with a longitudinal and transverse overlap of $60-80 \%$ using a DJI Phantom $4 \mathrm{c}$ unmanned aircraft system. The methods used were discussed in more detail in (Demidov et al., 2016, 2019; Koshurnikov et al., 2019).

Published works on underground waters and permafrost of Svalbard used for the analysis of previous studies included the following: the collection of scientific works of Sevmorgeologiya (Gidrogeologiya..., 1983), articles by N.I. Obidin (1958) and B.I. Vtyurin (1989,
1990), and engineering-geological and hydrogeological reports of 1935-1989 from the archives of the Spitsbergen Party of the Stock Venture Polar Marine Geosurvey Expedition in Barentsburg (Rossiiskie..., 1998).

\section{RESULTS AND DISCUSSION \\ Distribution, Thickness, and Temperature
of the Frozen Layer}

The studied area is characterized by continuous distribution of permafrost. The thickness of rocks with temperatures below zero is about $100 \mathrm{~m}$ near the coastal zone (Obidin, 1958) and increases to $400-540 \mathrm{~m}$ on watersheds. According to data by M.N. Mirzaev et al. (cited by (Rossiiskie..., 1998)), the maximal thickness of rocks with a negative temperature is recorded near the settlement of Kolsbey in well 31: $540 \mathrm{~m}$ at an altitude of the well mouth of $526 \mathrm{~m}$ above sea level. At the Barentsburg mine, the maximal thickness of deposits with negative temperature exceeds $310 \mathrm{~m}$ in well 248 (Obidin, 1958) with an altitude of the mouth of $221 \mathrm{~m}$.

The thermometric curves of exploration wells obtained in the 1930s-1950s are given in Fig. 3. The temperature curves below the layer of seasonal temperature fluctuations tend to bend towards positive temperatures in most wells. This is probably related to the cycle of climate warming, which began prior to measurements and continues at the present time. According to measurements in the Grumant parametric well, the mean geothermal gradient is $2.9^{\circ} \mathrm{C} / 100 \mathrm{~m}$ for Mesozoic and Cenozoic terrigenous rocks and $1.7^{\circ} \mathrm{C} / 100 \mathrm{~m}$ for Permian siliceous-carbonate rocks.

The minimal temperature of rocks under the layer of seasonal fluctuations in $1930-1950$ was $-3.6^{\circ} \mathrm{C}$ (Fig. 3). According to data by I.Yu. Misnik and K.N. Belousov (1983), this parameter varies from -3.2 to $-2.4^{\circ} \mathrm{C}$ at a depth of $11-40 \mathrm{~m}$ in the region of Barentsburg, which in general corresponds to the modern data (Table 1, Fig. 4). The year-round temperature monitoring is now performed in eight RAE-S wells, three of which are included in the GTN-P system: wells 2, 9, and 12 (codes in the GTN-P database are RU 202, RU 204, and RU 201, respectively). The thermometric wells enable the temperature monitoring of different kinds of deposits: of the accumulative sea terrace (well 2), rocky ground (well 12), long-term heaving mounds (wells 9, 13, and 15), and taliks under river beds (wells 17, 18, and 19).

The STL thickness is measured on the CALM monitoring site (code in the GTN-P database is Barentsburg CALM) at 121 points with a distance between them of $5 \mathrm{~m}$ at the end of the warm season after the first snowfall (in late September or in October). The CALM site is located at an altitude of about $75 \mathrm{~m}$ above sea level on a monadnock of the marine accumulative terrace $1.3 \mathrm{~km}$ southwest of the Barentsburg helicopter pad (Fig. 1). The deposits of the terrace are 


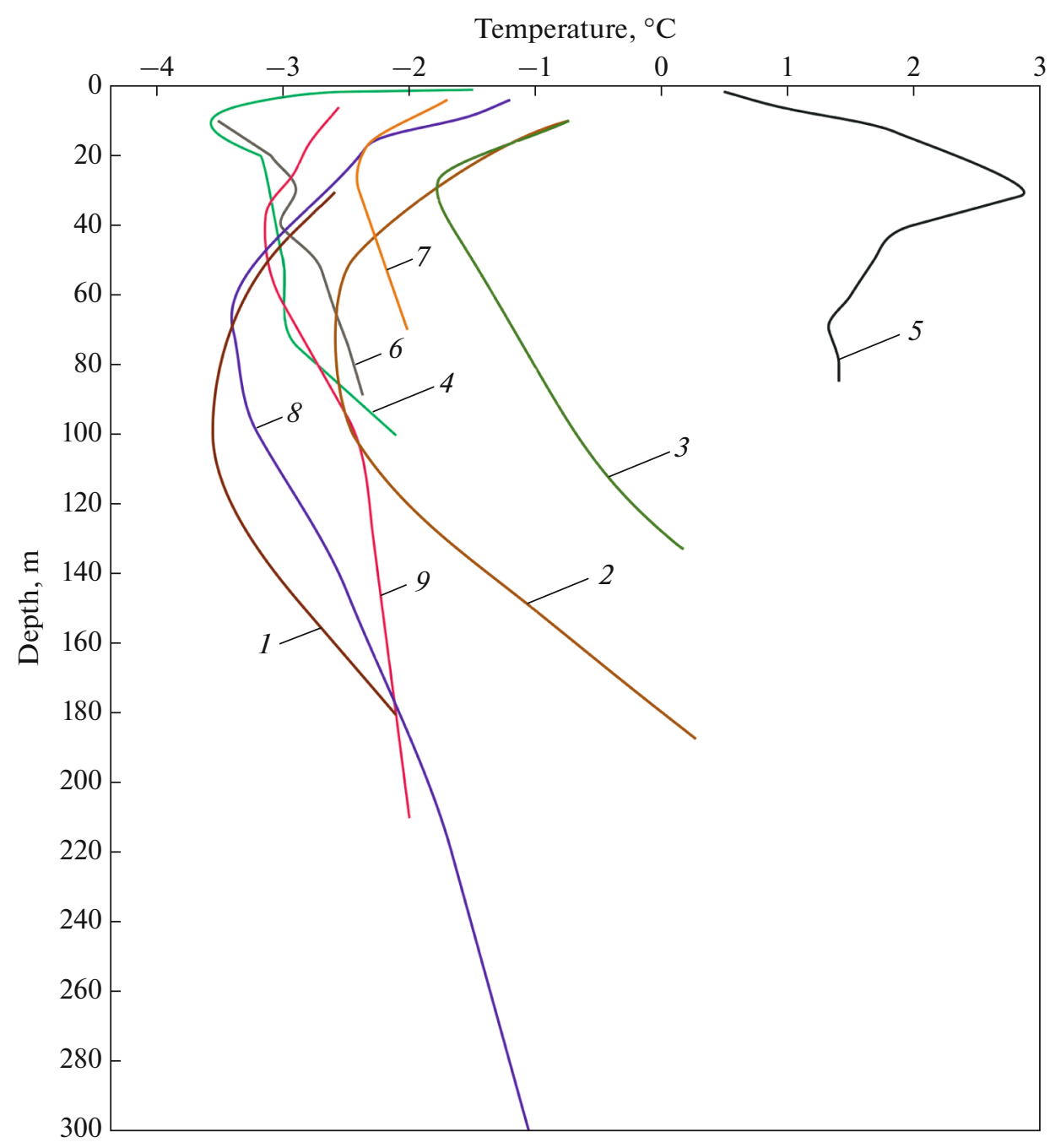

Fig. 3. Thermometric curves according to drilling data in the Soviet period. (1) Well 7, 1937; (2) well 13, 1937; (3) well 1, 1937; (4) well 240, 1952; (5) well 51, Fara Lake, 1957; (6) mine 5, Barentsburg, 1941; (7) well 251 (according to report from 1957); (8) well 248 (according to report of 1957); and (9) well 259 (according to report of 1957). Location of wells is given in Fig. 1.

characterized by thermometric well 2 allocated to the plot boundary. The terrace is composed of sandy-clay deposits with a massive cryogenic structure of $7 \mathrm{~m}$ thick (Demidov et al., 2016). An automatic weather complex is located near the site. The landscape of the site is formed by wood-rush-moss spotted tundra with the total projective cover of vegetation from 50 to $95 \%$. It is characterized by the presence of frost scars covered by a thin algae-lichen crust. Some of the spots are located on the open, sometimes rocky, surface. According to measurements of 2019, the STL thickness on the site ranges from 114 to $154 \mathrm{~cm}$ with a mean of $133.5 \mathrm{~cm}$. In 2017 and 2018, the mean STL thickness was 138 and $144.5 \mathrm{~cm}$, respectively. In some areas of the studied part of the Nordenskiold Land, in places of the warming effect of seasonal water flows in particular, the STL thickness may be significantly greater, exceeding 3-4 m.
Continuous frozen rocks are interrupted in areas of shelf, under-lake, glacial, and water-thermal taliks. According to data by M.N. Mirzaev et al (cited by (Rossiiskie..., 1998)), the absence of frozen rocks under waters of sea bays was recorded by drilling nine engineering-geological wells in the water area of the Coles Bay by the Giproarktika Research Institute in 1956. The wells were drilled from the shoreline towards the water area at sea depths reaching $16 \mathrm{~m}$ to a distance of $317 \mathrm{~m}$. The maximal depth of wells from the sea bottom surface was $32 \mathrm{~m}$. The warming effect of the sea was also recorded by the temperature curve for well 7 of RAE-S drilled on Cape Finneset at a distance of $5 \mathrm{~m}$ from the edge of the 8-m-high sea terrace and at a distance of $20 \mathrm{~m}$ from the sea (Demidov et al., 2016). The temperature at a depth of $12.5 \mathrm{~m}$ on September 12, 2016, was $-0.87^{\circ} \mathrm{C}$. 
(a)

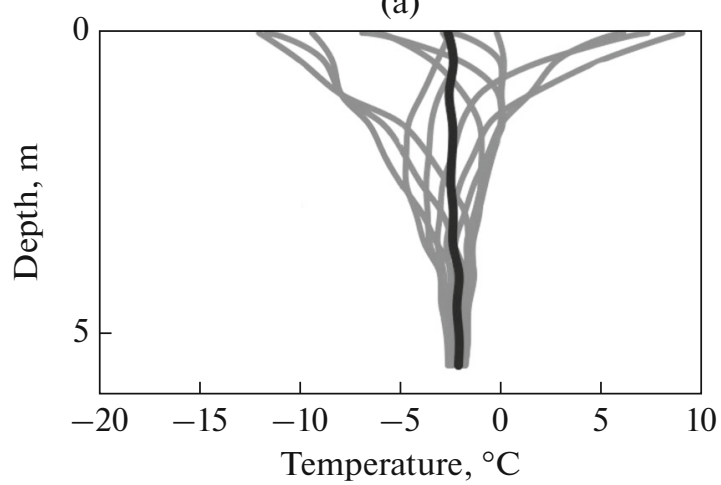

(b)

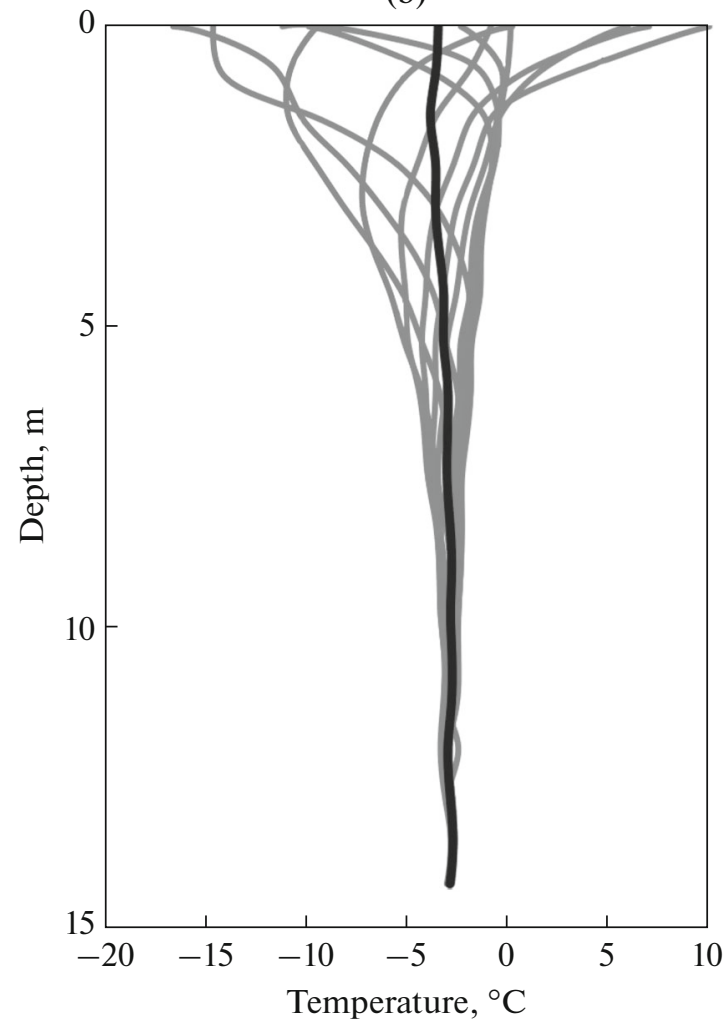

(c)

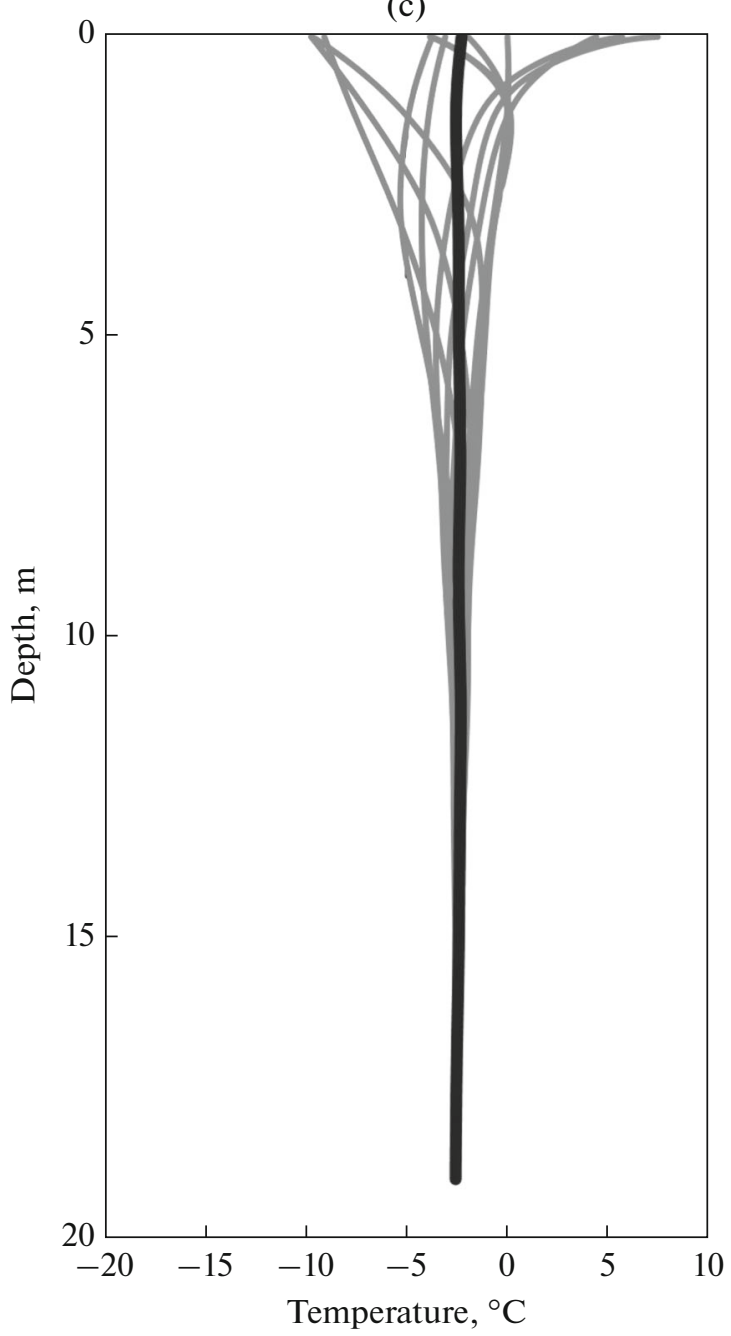

Fig. 4. Mean monthly temperature envelopes according to observation wells 2 (a), 9 (b), and 12 (c) (RAE-S; September 25, 2018August 25, 2019). Location of wells is given in Fig. 1.

Extensive through taliks near the mouths of the Grønfjorden and Grendalen valleys stretch from the sea for several kilometers. They were discovered during electrical exploration by the EM method in 2019 (Figs. 1, 5). Low electrical resistivity (Om m) indicate that the rocks contain saline unfrozen water. High-resistance layers, underlying the low-resistance ones at the bottom of the section, may correspond to the rock base or frozen rocks of the Quaternary age. In the geo-electric section in the Grønfjorden valley, the thickness of the top high-resistance layer of frozen rocks, which covers the talik, regularly increases from the first meters on the coast edge to $10 \mathrm{~m}$ at a distance of $350 \mathrm{~m}$ from the sea (Fig. 5, section A1-A2). The first two measurements on this profile were made from the fast ice; the absence of high-resistance rocks in them testifies to the absence of a canopy of frozen rock extending into the sea. In the lower reaches of the Grendalen Valley, the top part of the geoelectric section to a depth of 3-7 $\mathrm{m}$ is represented by strongly resistant frozen rocks, which cover the talik (Fig. 5, sections $\mathrm{B} 1-\mathrm{B} 2, \mathrm{C} 1-\mathrm{C} 2)$. The formation of this talik zone is a result of two processes: the infiltration of sea water in the valley mouth and the formation of cryopegs by pressing out of salts during the freezing of marine sediments. The relatively recent rise of the lower parts of the valleys above sea level, when there was sufficient time for freezing of sediments, may 
Table 1. Characterization of wells and data of thermometric measurements on the Barentsburg Cryologic Test Plot

\begin{tabular}{|c|c|c|c|}
\hline $\begin{array}{l}\text { Well no.: } \\
\text { coordinates, } \\
\text { mouth altitude } \\
\text { above sea level }\end{array}$ & $\begin{array}{l}\text { Geomorphologic position and generalized } \\
\text { lithological section (rocks are frozen) }\end{array}$ & $\begin{array}{c}\text { Depth/mean annual } \\
\text { temperature by lower sensor }\end{array}$ & $\begin{array}{c}\text { Depth/temperature } \\
\text { by lower sensor, single } \\
\text { measurement }\end{array}$ \\
\hline $\begin{array}{l}\text { well 2: } \\
78.09504^{\circ} \mathrm{N} \\
14.24096^{\circ} \mathrm{E} \\
75.5 \mathrm{~m}\end{array}$ & $\begin{array}{l}\text { Accumulative sea terrace on the southern shore } \\
\text { of Isfjorden: } \\
0-7 \mathrm{~m}-\text { sand and loam; } \\
7.0-7.5 \mathrm{~m} \text {-rock }\end{array}$ & $\begin{array}{l}5.5 \mathrm{~m} /-2.17^{\circ} \mathrm{C} \\
(\text { September } 24,2018-\text { Sep- } \\
\text { tember } 24,2019)\end{array}$ & \\
\hline $\begin{array}{l}\text { well 7: } \\
78.04703^{\circ} \mathrm{N} \\
14.21962^{\circ} \mathrm{E} \\
8.0 \mathrm{~m}\end{array}$ & $\begin{array}{l}\text { Sea terrace on Cape Finneset: } \\
0-9 \mathrm{~m}-\text { gravelly sand and sandy loam; } \\
9-12.5 \mathrm{~m} \text { loam; } \\
\text { (pebble is at the bottom) }\end{array}$ & & $\begin{array}{l}12.5 \mathrm{~m} /-0.87^{\circ} \mathrm{C} \\
(\text { September } 12,2016)\end{array}$ \\
\hline $\begin{array}{l}\text { well 8: } \\
78.02068^{\circ} \mathrm{N} \\
14.40860^{\circ} \mathrm{E} \\
16.0 \mathrm{~m}\end{array}$ & $\begin{array}{l}\text { Swollen terrace (hydrolaccolith) on the right bank } \\
\text { of the Gren River: } \\
0-1.5 \mathrm{~m} \text {-gravel and pebble with loamy substrate; } \\
1.5-25 \mathrm{~m}-\text { loam and siltstone with ice layers } \\
\text { reaching } 1 \mathrm{~m} \text { in thickness }\end{array}$ & & $\begin{array}{l}14.5 \mathrm{~m} /-3.56^{\circ} \mathrm{C} \\
(\text { September } 14,2017)\end{array}$ \\
\hline $\begin{array}{l}\text { well 9: } \\
77.99355^{\circ} \mathrm{N} \\
14.6621^{\circ} \mathrm{E} \\
53.0 \mathrm{~m}\end{array}$ & $\begin{array}{l}\text { Crater on the summit of the heaving mound } \\
\text { in the Grendalen Valley: } \\
0-1.5 \mathrm{~m} \text {-loam; } \\
1.5-23.8 \mathrm{~m} \text {-massive ice; } \\
23.8-25 \mathrm{~m} \text {-clay }\end{array}$ & $\begin{array}{l}14.25 \mathrm{~m} /-2.6^{\circ} \mathrm{C} \\
\text { (September } 22,2018-\text { Sep- } \\
\text { tember } 22,2019)\end{array}$ & \\
\hline $\begin{array}{l}\text { well 12: } \\
78.09075^{\circ} \mathrm{N} \\
14.20244^{\circ} \mathrm{E} \\
95.0 \mathrm{~m}\end{array}$ & $\begin{array}{l}\text { Accumulative terrace on the southern shore } \\
\text { of the Isfjorden: } \\
0-2 \mathrm{~m} \text {-gravelly loam with inclusions of pebble; } \\
2-19 \mathrm{~m} \text {-fractured sandstone }\end{array}$ & $\begin{array}{l}19.0 \mathrm{~m} /-2.57^{\circ} \mathrm{C} \\
\text { (September } 22,2018-\text { Sep- } \\
\text { tember } 22,2019)\end{array}$ & \\
\hline $\begin{array}{l}\text { well 13: } \\
77.99483^{\circ} \mathrm{N} \\
14.59009^{\circ} \mathrm{E} \\
42.5 \mathrm{~m}\end{array}$ & $\begin{array}{l}\text { Top of the Nori heaving mound in the Grendalen } \\
\text { Valley: } \\
0-4.4 \mathrm{~m}-\text { gravel and pebbles with layers of sandy } \\
\text { loam and loam; } \\
4.4-20.5 \mathrm{~m}-\mathrm{ice} \text {; } \\
\text { 20.5-22.0 m-gravel and pebbles with loamy } \\
\text { material }\end{array}$ & & $\begin{array}{l}21.8 \mathrm{~m} /-2.58^{\circ} \mathrm{C} \\
\text { (April 4, 2019) }\end{array}$ \\
\hline $\begin{array}{l}\text { well 15: } \\
14.66742^{\circ} \mathrm{N} \\
77.99398^{\circ} \mathrm{E} \\
60.5 \mathrm{~m}\end{array}$ & $\begin{array}{l}\text { The top of the Kili heaving mound in the Gren- } \\
\text { dalen Valley: } \\
0-13.5 \mathrm{~m}-\text { gravel and pebble with sand and clay } \\
\text { material; } \\
13.5-14.0 \mathrm{~m} \text {-ice }\end{array}$ & & $\begin{array}{l}14.25 \mathrm{~m} /-2.87^{\circ} \mathrm{C} \\
(\text { September } 22,2019)\end{array}$ \\
\hline
\end{tabular}

also be important. The geoelectric section in the Coles Valley is more complicated. There is a highresistance layer between low-resistance ones at a depth of 8-13 m, which may be related to the presence of icy rocks (Fig. 5, section F1-F2).

According to the EM data, the talik zone with the resistance of several units $(\mathrm{Om} \mathrm{m})$ under Grendal Lake may be traced at least to a depth of $31 \mathrm{~m}$ at a distance of $2.3 \mathrm{~km}$ from the sea in the Grendalen Valley (Figs. 1, 6a). In deeper layers, the resistance increases, which may be related to frozen rocks or to the appearance of the underlying bedrock. According to data by
M.N. Mirzaev et al. (cited by (Rossiiskie..., 1998)), the presence of a through talik under Fara Lake in the mouth of the Coles Valley is proved by the thermometric analysis of the 85-m-deep well 51 (Fig. 3) drilled from ice in the center of the lake in 1957. Taliks between frozen layers, the roof of which is located at depths from 10 to $20 \mathrm{~m}$, are also revealed in the Grendalen Valley under the Oin and Gloin pingo (Figs. 1, 6, sections D1-D2, E1-E2). There is also a thin talik at a depth of 15-16 $\mathrm{m}$ near the slope of the Grendalen Valley to the south of the Nori pingo (Figs. 1, 6c). In the Coles Valley, at a distance of $5 \mathrm{~km}$ from its mouth, 

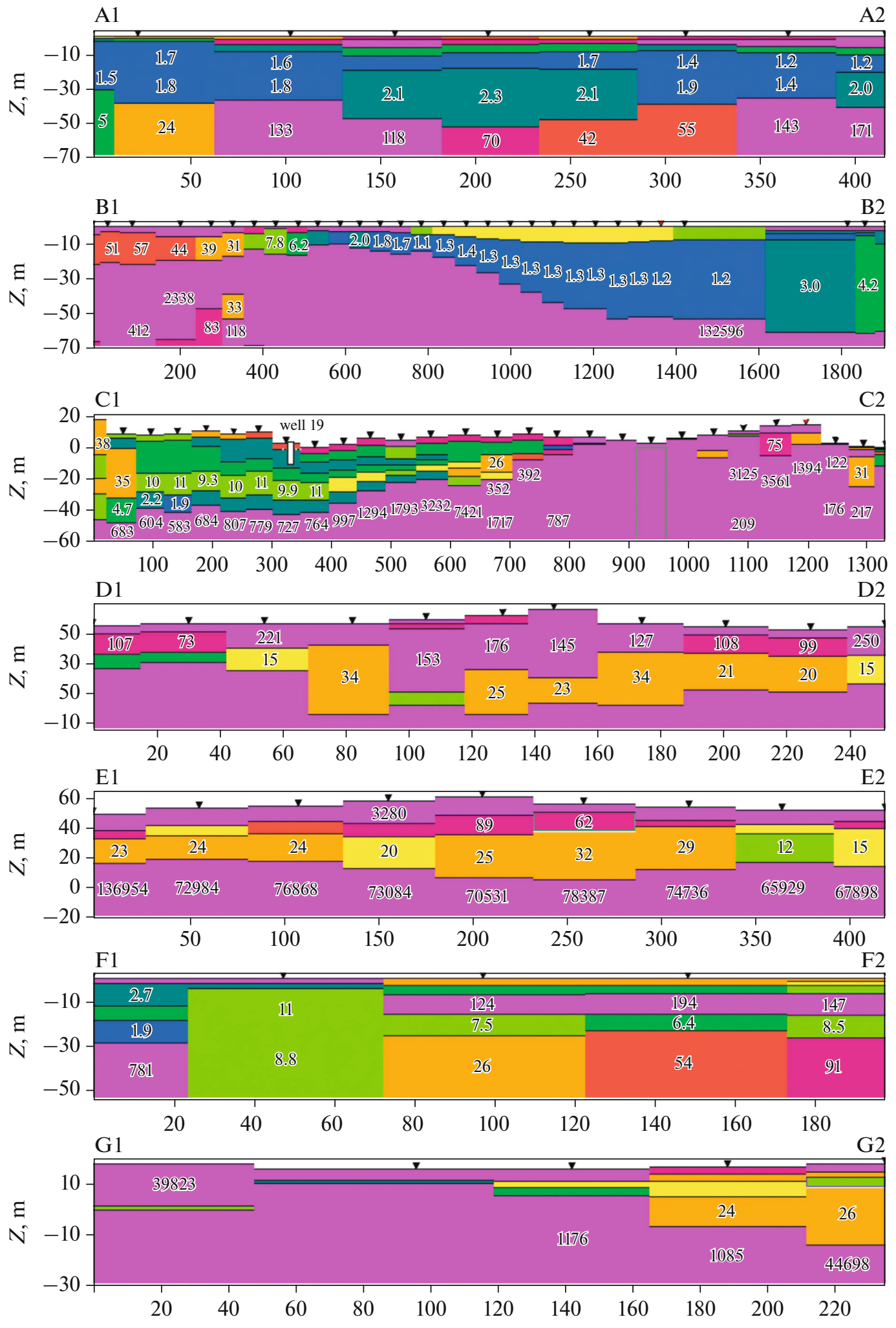

Resistivity $\rho$, Om m

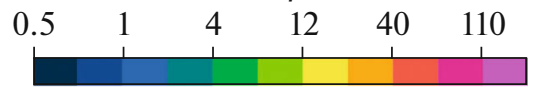

Fig. 5. Geoelectric sections by data from EM sounding. Location of the sections is given in Fig. 1: (A1-A2) Grønfjorden Valley, (B1-B2 and C1-C2) Grendalen Valley, (D1-D2) Gloin pingo, (E1-E2) Oin pingo, and (F1-F2 and G1-G2) Coles Valley. 
(a)

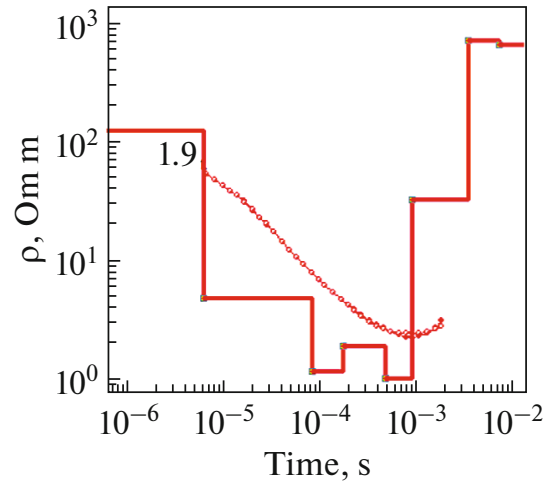

(b)

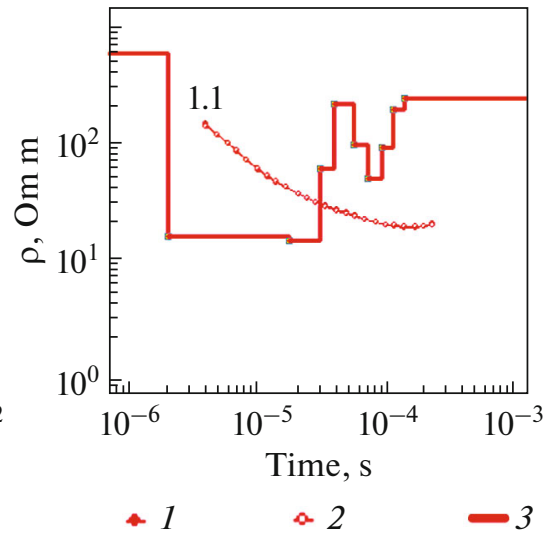

(c)

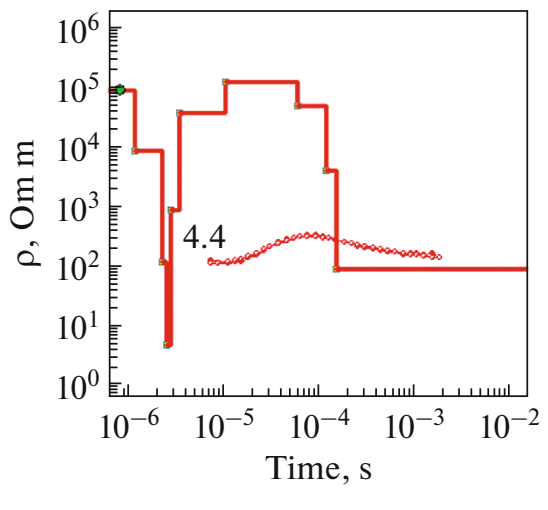

Fig. 6. EM sounding curves: (a) talik under the Grendal Lake in the Grendalen Valley, (b) talik under an blister on the Gren River $1.3 \mathrm{~km}$ from the sea, and (c) talik near the slope of the Grendalen Valley to the south of the Nori pingo. (1) Actual curve, (2) model curve, and (3) parameters of model layers.

there is a talik about 10 -m-thick under the riverbed (Figs. 1, 5, geoelectric section G1-G2). The existence of permanent spring and blisters with liquid water on the eastern and western coasts of Grønfjorden (Fig. 1) testifies to the formation of a number of water-thermal taliks there. The frozen layer is interrupted under some large glaciers, which is described in detail in the Underground Water section.

\section{Cryogenic Structure of Deposits}

The cryogenic structure of the Quaternary deposits may be described by the analysis of wells drilled as part of works of RAE-S in 2016-2020. The data on the cryogenic structure of hard rocks are now very fragmentary. There are only notes in the reports (Rossiiskie..., 1998) that rocky ground in mines and exploration wells in Barentsburg contained ice layers reaching several centimeters thick. Wells drilled since 2016 characterize the accumulative sea terraces on the southern coast of Isfjorden; the terrace of Cape Finneset; the Grendalen and Hollendar mountain valleys composed of marine, slope, and river deposits; and pingos in the Grendalen Valley. The maximal thickness of the Quaternary deposits is $21.5 \mathrm{~m}$ in well 8 on a terrace in the Grendalen Valley. According to the data of the EM, the total thickness of Quaternary deposits in the area of this well may reach about 50-60 m (Fig. 5, section $\mathrm{B} 1-\mathrm{B} 2$ ).

In most wells, the top part of the section is represented by coarse-grained gravel, rotted rock, and pebbles with or without loam and sandy loam material between them. The genesis of this geological series is related to destruction of bedrock (argillites and sandstones) and their further processing under conditions of beach. Slope and fluvioglacial deposits in valleys are processed by rivers. This is proven by the rounded shape of the fragments. This part of the section is character- ized by a massive cryogenic structure, mainly of a pore type, and less often of film and contact type (Fig. 7a). The mean water content of deposits is $25 \%$. The total content of water-soluble salts is hundredths and thousandths of a percent of the mass of dry sample.

On the contrary, the bottom of wells composed of marine sediments is characterized by a loamy composition (Fig. 8). These deposits are usually gray and sometimes brown or black. The loam may contain rare rounded fragments or layers of gravel with rotted rock. The cryogenic structure is schlieren (Fig. 7d). Subvertical and subhorizontal ice schliers several centimeters in width are located at a distance of several decimeters from each other. There are also ice inclusions and lenses. The mean water content of these deposits is $38 \%$.

The total content of water-soluble salts in the coarse-grained series is hundredths and thousandths of a percent of the mass of dry sample. The taste of loamy deposits is often slightly saline: the content of water-soluble salts varies here from tenths to the first percent of the mass of dry sample. The cation composition of the water extract from the both series is characterized by the domination of $\mathrm{Na}^{+}$or $\mathrm{K}^{+}$(Fig. 9). The domination of any one anion was not detected, except for well 8, where $\mathrm{Cl}^{-}$dominates the loam series.

According to the type of freezing, the loam series is epicryogenic, while freezing of the coarse-grained series may be both epicryogenic and syncryogenic. Segregation and injection ice of various thicknesses is uncovered in a number of wells (it is discussed in the next section).

\section{Cryogenic Geological Processes and Phenomena}

Cryogenic processes typical for mountain regions and lowlands are developed in the studied area. High plateau and mountain slopes undergo cryogenic 

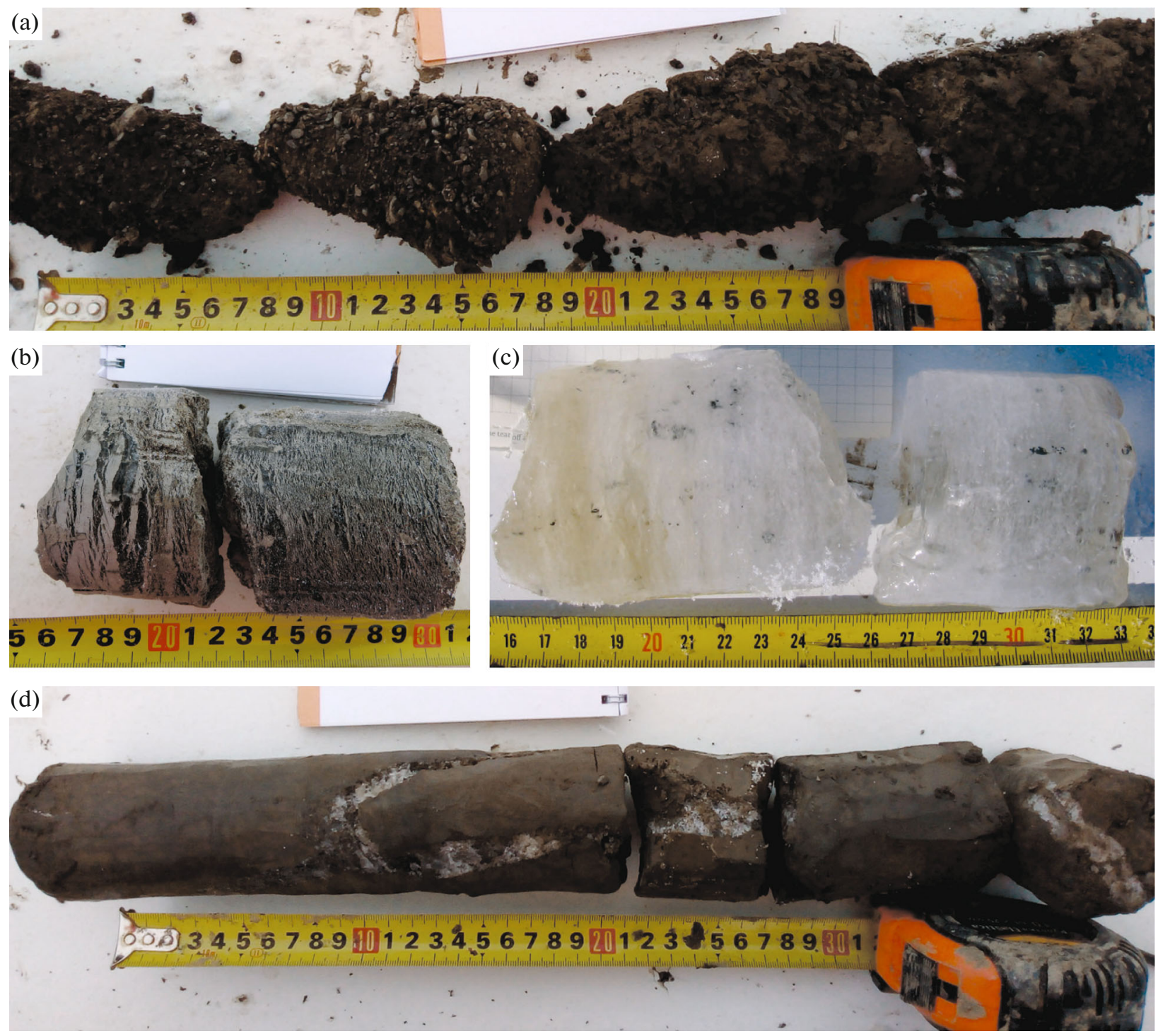

Fig. 7. Core samples of frozen sediments: (a) gravel of massive cryogenic structure from a depth of 2.8-3.2 m (well 15), (b) iceoversaturated deposits from a depth of 3.4-3.6 m (well 16), (c) injection ice from a depth of 17.5-17.7 m (well 9), and (d) loam with a large subvertical ice schlier from a depth of 11.2-11.6 $\mathrm{m}$ (well 15).

weathering, material transportation by stone streams, and frost sorting, resulting in the appearance of stone rings, stripes, and spots of frost scars. The solifluction transportation of material (Fig. 10a) is seen almost everywhere in the area: in piedmonts, on moraine complexes, on sea terraces, and in the bottoms of valleys. Stone glaciers are formed at the foot of the talus slopes in the Coles Valley. Frost heaving, resulting in the formation of seasonal and perennial mounds (Fig. 10b), and frost cracking with the appearance of polygonal topography (Fig. 10c) are developed in some areas in valleys. A description of an ice wedge in the section of a terrace $15 \mathrm{~km}$ from the mouth of the Gren River is given in (Vtyurin, 1990). Its width at the top is $8 \mathrm{~cm}$, and the vertical length is more than $2 \mathrm{~m}$. The author supposes that this is a fossil epigenetic vein.
Classical polygonal forms are rare in the Grendalen and Hollendar valleys (only some long cracks are seen here), while the Coles Valley is characterized by welldeveloped polygonal relief, two types of which are distinguished. The first complicated type, with sides of polygons $10-20 \mathrm{~m}$ in length, is formed in peaty areas of the floodplain, probably by wedge ice. The second type is spread on the sea terrace composed of pebblygravel deposits and is represented by a rectangular pattern with a side of 5-10 m. Polygonal relief with sides of rectangles of $10-25 \mathrm{~m}$ in combination with karst forms is also described on boulder-pebble deposits on the western coast of Grønfjorden in the mouth of the Linne River on marine terraces (Akerman and Boardman, 1987; Sharin et al., 2012). According to (Matsuoka et al., 2004), these polygons are formed by ground wedges. 


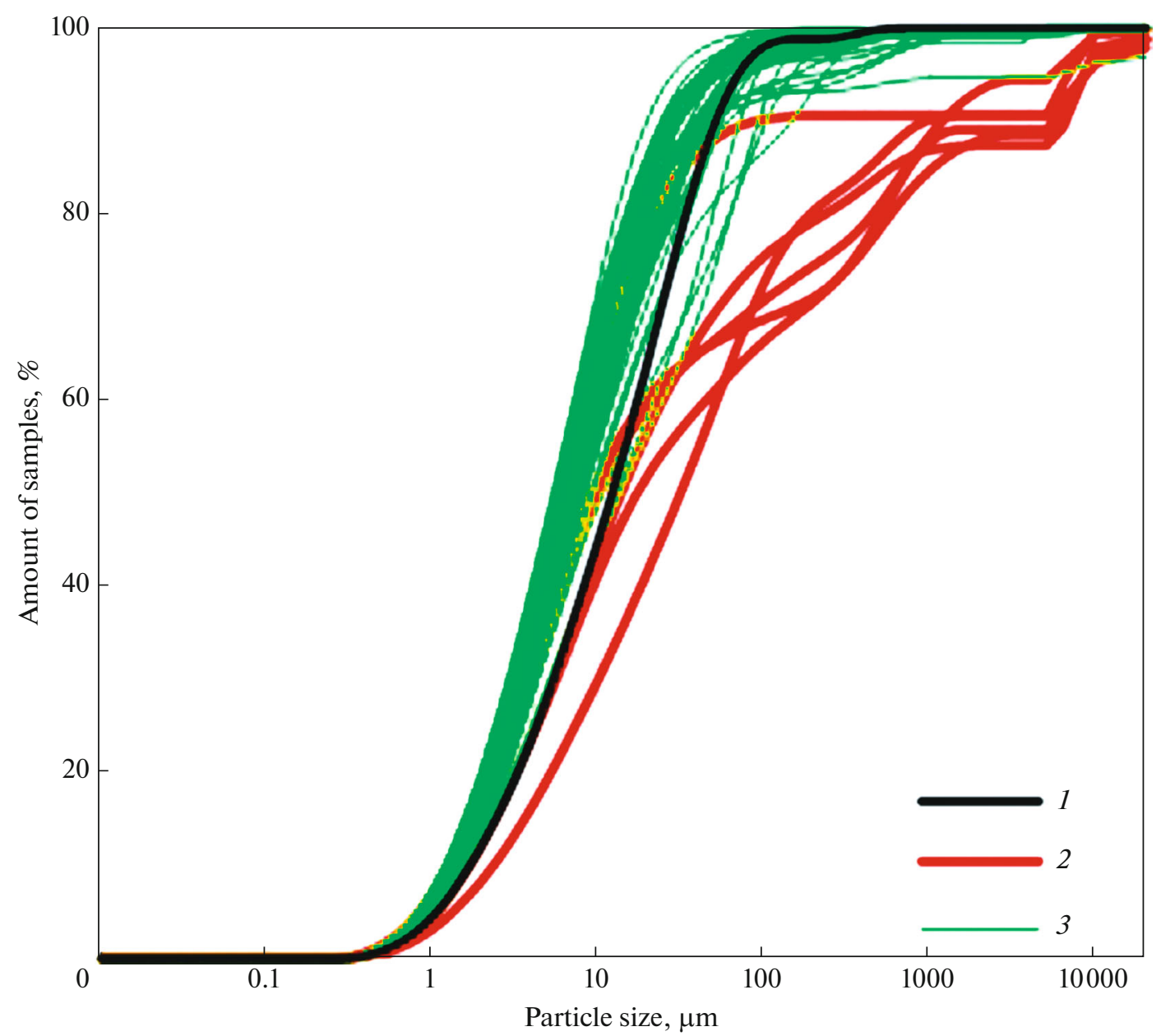

Fig. 8. Cumulative curves of the particle-size composition of deposits in well 8. Sampling depth, m: (1) 0.1-0.3, (2) $0.3-1.3$, and (3) $1.5-20.35$.

Relatively warm permafrost, active tectonics, and glacial groundwater supply cause a wide range of processes related to groundwater discharge, which is not typical for high-latitude Arctic archipelagos (these processes are discussed in detail in the Groundwater section). Large hydrogeogenic icings formed in areas of groundwater discharge disappears in summer (Fig. 10d). Icings are also formed in the margins of large mountainvalley glaciers Dalfonna, West Grønfjorden, East Grønfjorden, Aldegonda, Tavle, and Tunge. Ice mounds (blisters) appear on the surface of icings (Fig. 10e).

Ice mounds are also formed in riverbeds due to the freezing of taliks under the riverbed. Large longterm heaving mounds-pingos (hydrolaccoliths)are revealed in the areas, where valley parts that emerged as a result of the sea regression are frozen over the places of groundwater discharge along tectonic faults. A group of hydrolaccoliths allocated to the Grendalen fault and characterized by the maximal relative height above the surrounding surface $(15 \mathrm{~m})$ is described in the Grendalen valley at a distance from 7 to $10 \mathrm{~km}$ from the mouth (Figs. 1, 11).
The results of hydrochemical and isotope analyses of core samples from well 9 (Demidov et al., 2019) show that the chemical composition of the ice core of the Fili pingo on the left bank of the Gren River is similar to that of the source of hydrocarbonate sodium water, emerging to the surface at the foot of the adjacent Oin pingo on the right bank of the river. The ice core of the Fili pingo uncovered by the well is 20.7-mthick and is underlain by frozen loam, which testifies to the talik freezing and to the end of the growth stage of the heaving mound. Ice thickness in well 13, which was drilled in the Nori pingo and is the closest to the sea, is $16 \mathrm{~m}$ (Demidov, V.E. and Demidov, N.E., 2019). The ice core is underlain by frozen gravelly deposits. Talik zones at depths of $20-40 \mathrm{~m}$ are detected under the Oin and Gloin pingos by the EM method (Fig. 5, sections D1-D2, E1-E2), which corresponds to the presence of the mentioned water source at the foot of the Oin mound. According to the geographic information resource of the Norwegian Polar Institute (https://toposvalbard.npolar.no/), a single small pingo is also revealed in the Hollendar Valley. However, the data from 12-m-deep well 20 drilled on its top in 2020 

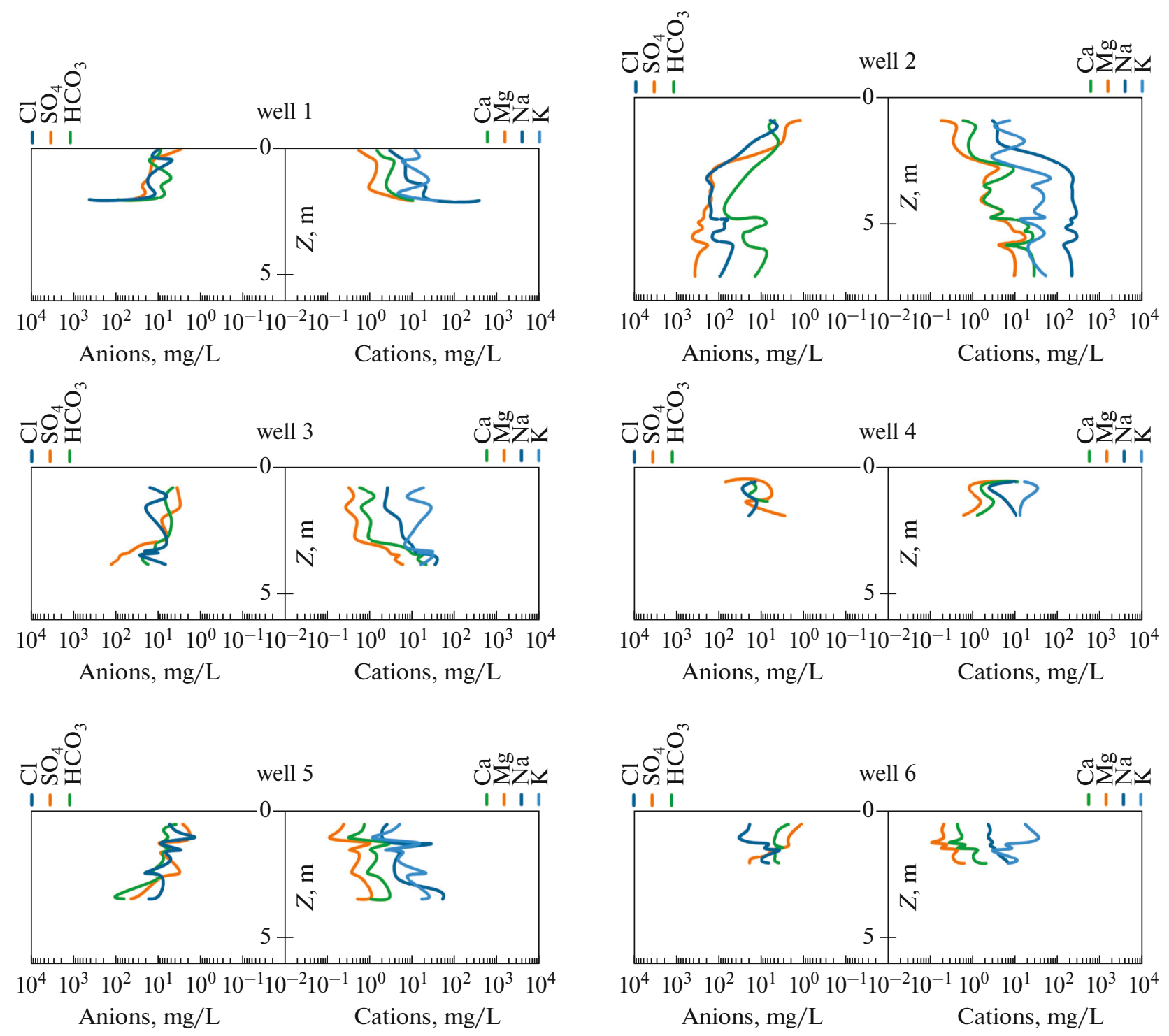

Fig. 9. Ion composition of water extract from core samples of Quaternary deposits. Location of wells is given in Fig. 1.

show that the ice core here is absent, which means that this outlier is not a heaving mound.

Under the warming climate, some of cryogenic processes are damped, while others become more intensive. Glaciers degrade over the research area. At the same time, the increasing STL thickness and more rains activate dynamic slope processes: landslides and mudslides (Figs. 10f, 10g), which are dangerous for the engineering infrastructure of settlements. The rise in the mean annual air temperatures and precipitation also cases the development of thermokarst processes on the surfaces, where moraines emerge from under glaciers, as well as in some places on the bottoms of the Grendalen and Hollendar valleys, where lenses of underground ice melt. An increase in the intensity of thermal erosion in the beds of permanent and temporary water flows should be expected. Thermoabrasion is, in general, slight due to the domination of rock cliffs along the sea coast; however, it is seen on the shores of Bretjorna Lake, which are composed of the terminal moraine with buried ice (Fig. 10h), and along the shoreline of capes Finneset and Kokeri, which are composed of loose sediments. Cryogenic processes and phenomena in the studied region are more comprehensively analyzed in (Demidov, V.E. and Demidov, N.E., 2019).

\section{Groundwater}

With respect to hydrogeological zoning, the studied area is assigned to the zone of the West Spitsbergen adartesian basin (Fig. 12). According to the map of hydrogeological zoning of western Spitsbergen compiled by Ya.V. Neizvestnov and V.I. Ivanov (Rossiiskie..., 1998), only a narrow strip reaching $10 \mathrm{~km}$ in 

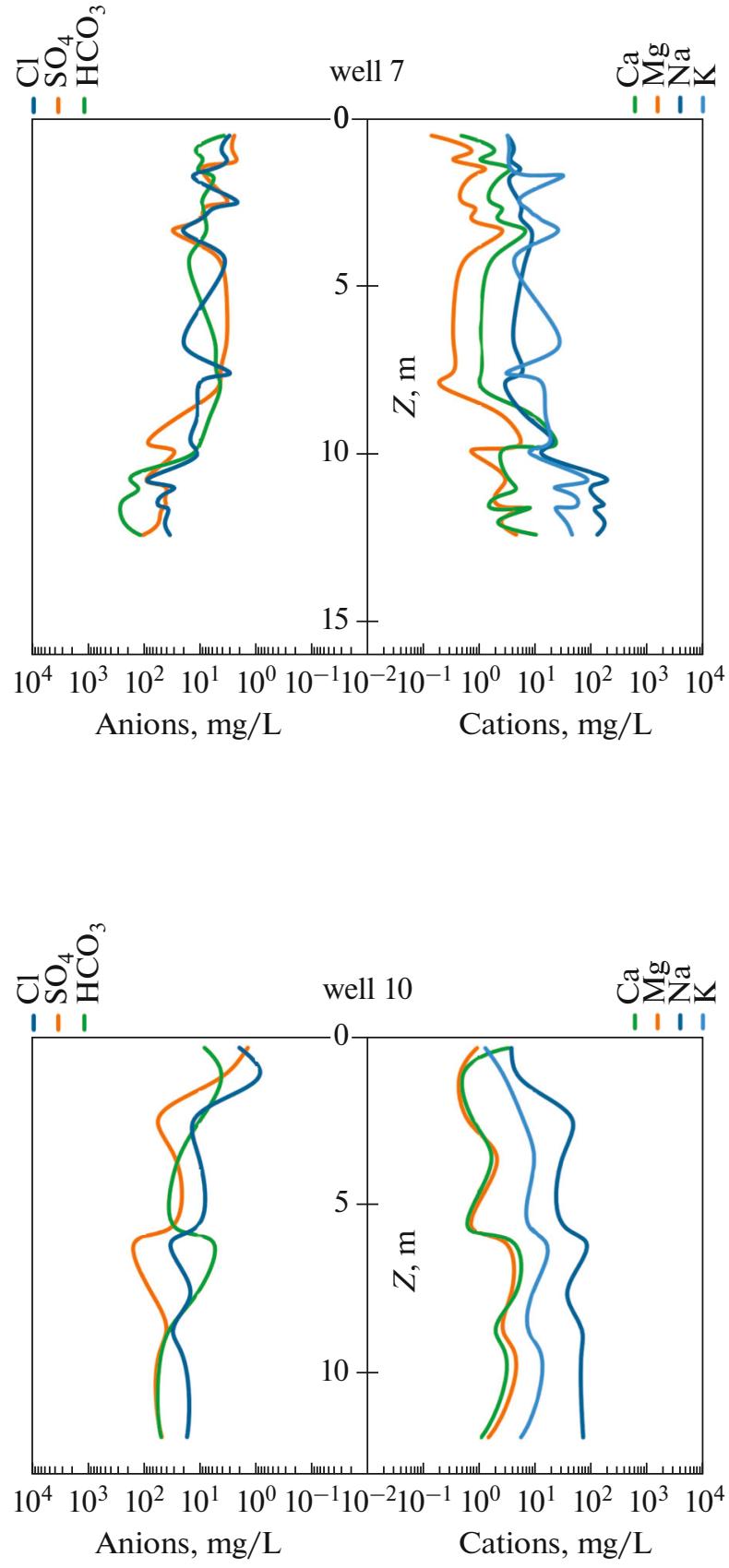
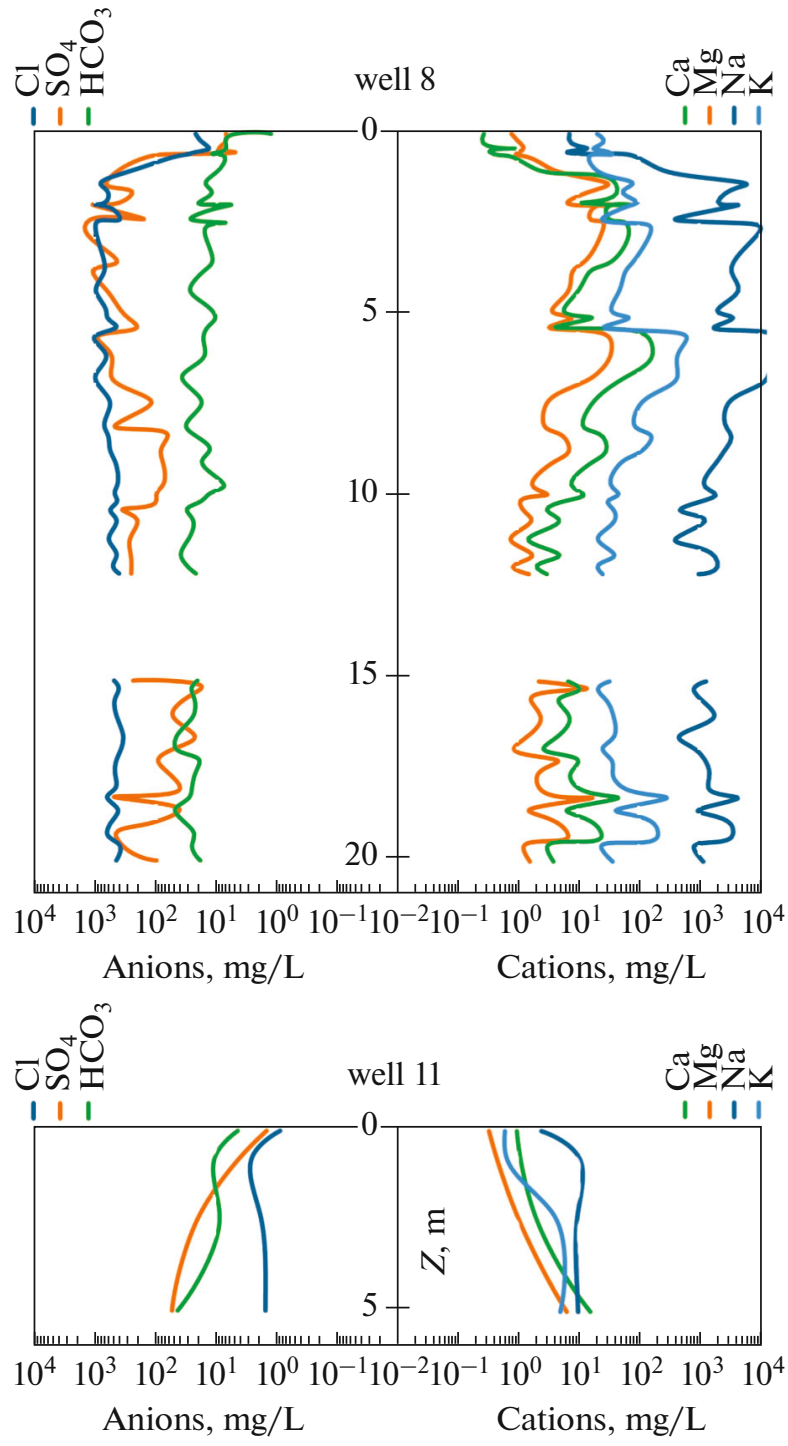

Fig. 9. (Contd.)

Fig. 10. Cryogenic processes in the studied region. (a) Solifluction terraces on the slope of the right bank of the Scar Valley (photo by V.E. Demidov, September 2019); (b) drilling camp of RAE-S on the top of the Nori pingo in the Grendalen Valley (photo by S.S. Voronezhskii, March 2019); (c) ice crack surrounded by frost scars in the Grendalen Valley (photo by V.E. Demidov, September 2019); (d) icing at the confluence of the Tro Valley in the Coles Valley (photo by S.S. Voronezhskii, April 2019); (e) blister near the terminal moraine of the Tunge glacier in the upper reaches of the Grendalen Valley (photo by A L. Nikulina, May 2019); (f) landslide on the right slope of the Grendalen Valley in the middle reaches (photo by V.E. Demidov, September 2019); (g) landslide and erosion hollows above the hotel, residential building, and the RAE-S laboratory in Barentsburg (photo by V.E. Demidov, September 2019); and (h) consequences of thermal erosion of the Bretjorna Lake shores (photo by V.E. Demidov, April 2019). 

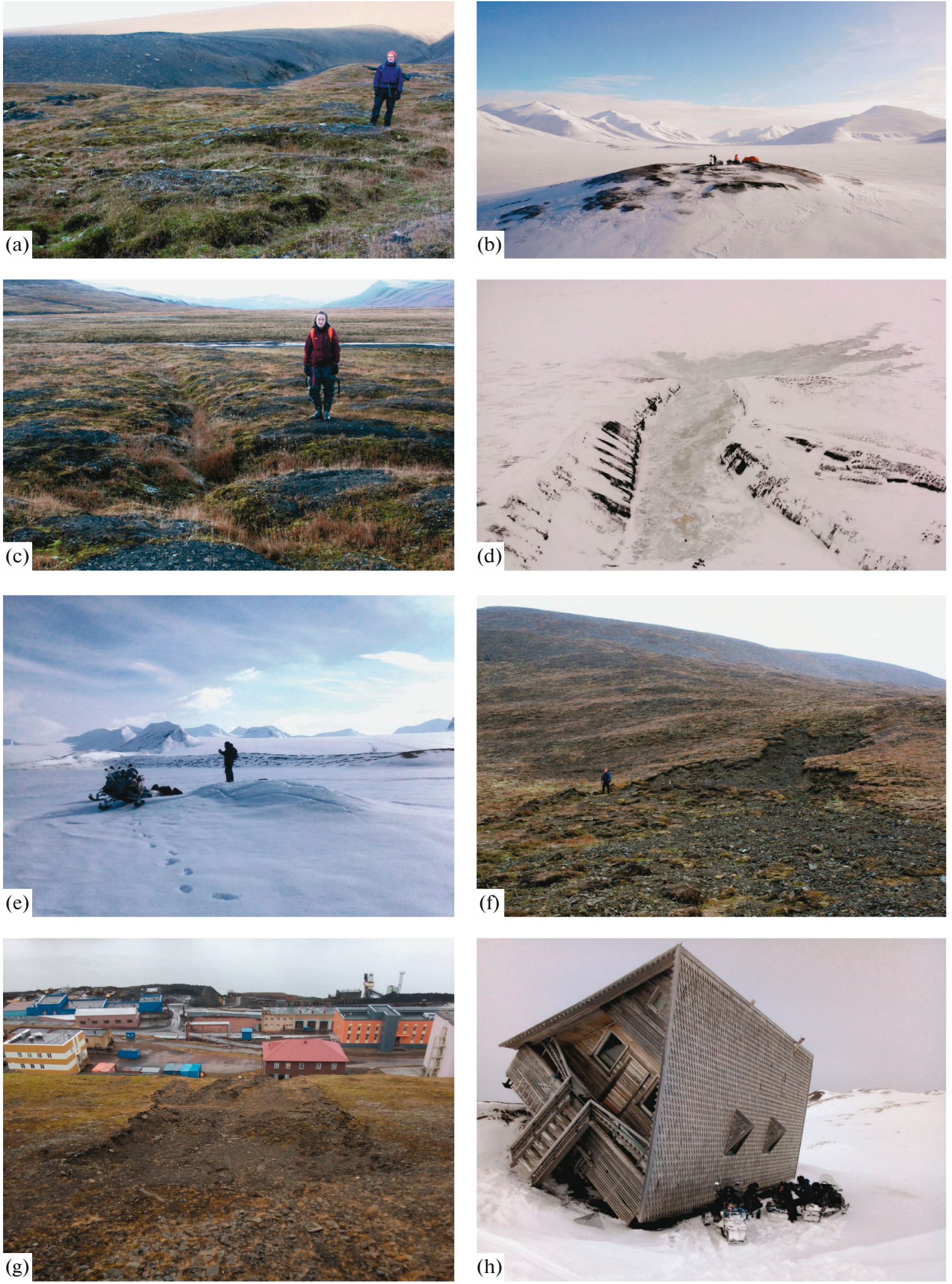


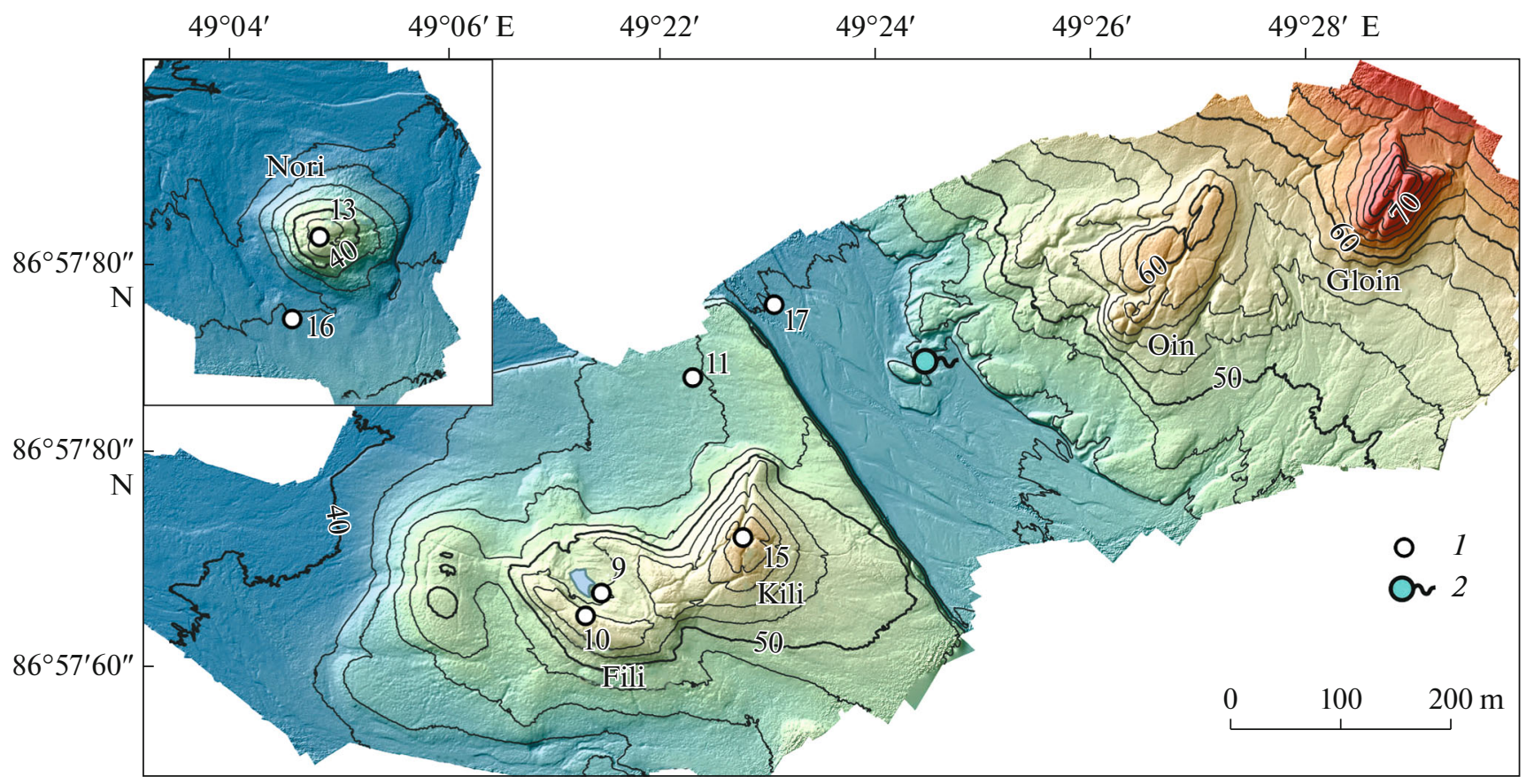

Fig. 11. Topography in areas of pingos in the Grendalen Valley by aerophotogrammetry. (1) Drilling sites; (2) Oin source. Isolines are drawn every $2 \mathrm{~m}$.

width with altitudes no higher than $50 \mathrm{~m}$ above sea level along the western coast of the Nordenskiold Land is allocated to the zone of the Rusanov Hydrogeological Massif. A significant part of the West Spitsbergen adartesian basin is located in the sea area. Its part emerged from the sea is characterized by a frozen zone, which is absent on the sea bottom. One important feature of the basin consists of the subglacial supply of groundwater, which will be shown below. All this affects the hydrogeochemical zoning and conditions of groundwater formation. According to the classification of hydrogeological structures undergone freezing (Romanovskii, 1983), this should be called the cryoadartesian basin. The general vertical hydrodynamic and hydrochemical zoning of the West Spitsbergen Basin within the studied area is given below.

The zone of free water exchange includes only waters of the STL and above-permafrost taliks. Numerous sources of water of the seasonally thawed layer in Quaternary sediments function in the warm season. Their discharge is up to $3 \mathrm{~L} / \mathrm{s}$. The thickness of the layer reaches $1.5-3 \mathrm{~m}$ and is maximal in river valleys and lower parts of slopes. Filtration rates are rather high, which is mainly explained by coarsegrained surface deposits and the inclination of the surface. This layer is recharged at the beginning of year mainly by snow-melt water. Then, the main role is plaid by liquid precipitation, water from glaciers, and moisture released during pore ice melting. Groundwater is discharged into temporary watercourses, streams, and rivers. The chemical composition of waters in the STL is variegated, which is related to the high leaching effect of glacial and atmospheric waters on the surrounding rocks. These are sulfate bicarbonate, magnesium calcium, or sodium calcium waters typical for coastal-marine areas of the leaching zone of humid areas. According to data by I.S. Postnov (cited by (Rossiiskie..., 1998)), the generalized chemical composition of waters in the STL is the following:

$$
M_{0.025-0.270} \frac{\mathrm{HCO}_{3}(44-86) \mathrm{SO}_{4}(20-30) \mathrm{Cl}(6-24)}{\mathrm{Ca}(44-66)(\mathrm{Na}+\mathrm{K})(10-58) \mathrm{Mg}(20-34)} \mathrm{pH}=4.1-9.6 .
$$

$M$ is mineralization, $\mathrm{g} / \mathrm{L}$; anions (percent equivalent) are above the line; and cations (percent equivalent) are under the line.
Waters of above-permafrost taliks are formed near the slopes of valleys on aprons as a result of the warming effect of a large volume of melt water flowing from the slopes in 


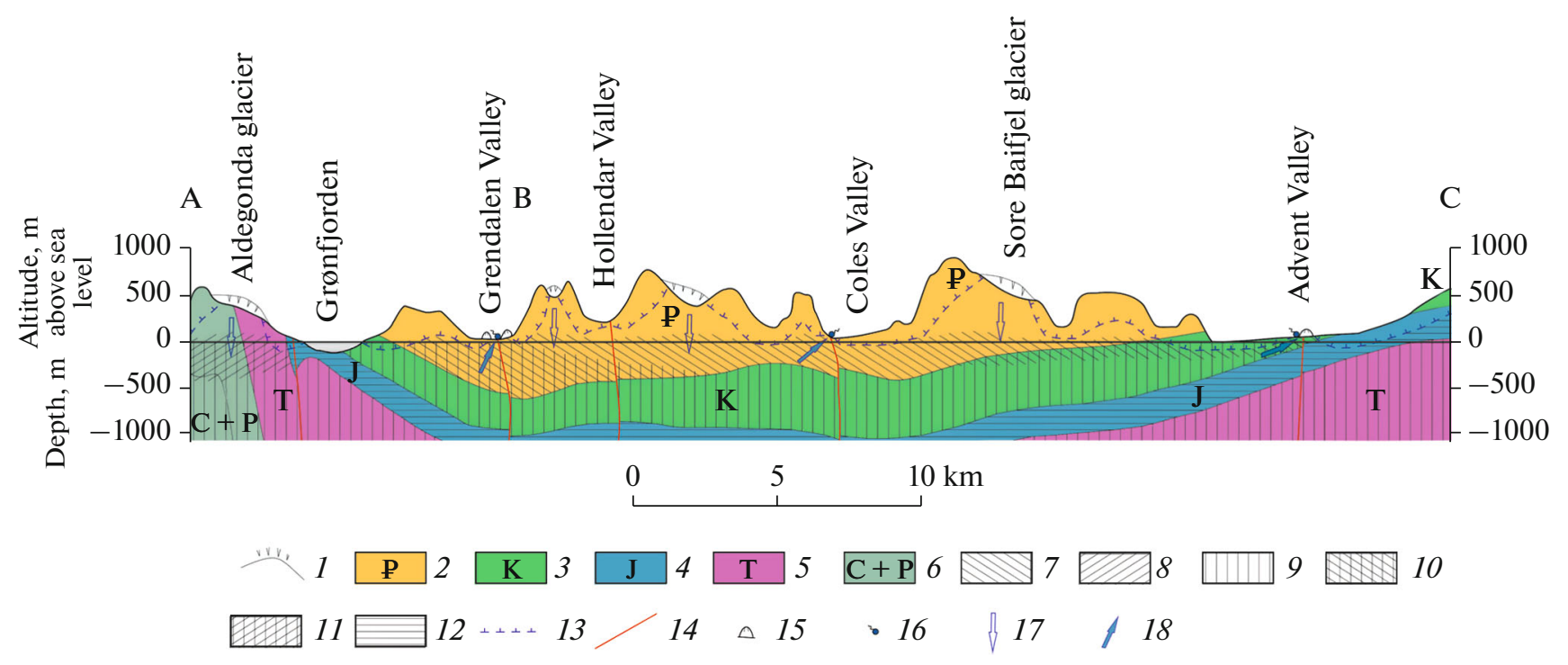

Fig. 12. Permafrost-hydrogeological section of the western Spitsbergen cryoadartesian basin. (1) Glaciers; (2) Paleogene aquifer of stratum-fissure and fissure-vein waters (summits are the zones of incomplete water saturation); (3) Lower Cretaceous aquifer of stratum-fissure, porous-fissure, and fissure-vein waters; (4) Aquiclude of Jurassic clay and clay shale; (5) Triassic aquifer of fissure and fissure-vein waters; (6) Carbon-Permian aquifer of stratum-fissure, fissure-vein, and fissure-karst waters; (7) fresh and slightly saline sodium bicarbonate water; $(8)$ fresh and slightly saline sulfate magnesium-calcium waters; (9) saline and strongly saline sodium chloride waters; $(10)$ possible simultaneous presence of saline and strongly saline sodium chloride waters and fresh and slightly saline sodium bicarbonate waters; (11) possible simultaneous presence of saline and strongly saline sodium chloride waters and fresh and slightly saline sulfate magnesium-calcium waters; (12) water-resistant layers; (13) lower boundary of frozen rocks; (14) discontinuities; (15) pingos; (16) underground water sources; (17) areas of subglacial groundwater supply; and $(18)$ areas of sodium bicarbonate water discharge.

spring. Above-permafrost taliks may be formed under riverbeds. By the end of winter, the main part of them apparently completely freezes. Waters are fresh sodium sulfate.
According to data by I.S. Postnov (cited by (Rossiiskie..., 1998)), the generalized chemical composition of waters in above-permafrost taliks is sodium sulfate:

$$
M_{0.431-0.573} \frac{\mathrm{SO}_{4}(67-93) \mathrm{HCO}_{3}(0.4-9.6) \mathrm{Cl}(0.3-2.3)}{(\mathrm{Na}+\mathrm{K})(81-89) \mathrm{Mg}(5.2-10.8) \mathrm{Ca}(3-5.5)} \mathrm{pH}=7-7.7
$$

Slightly different data on the composition of waters of permafrost taliks in the Gren River valley are given in the work by A.D. Kasatkin and Ya.V. Neizvestnov (1983):

$$
M_{0.17-0.38} \frac{\mathrm{SO}_{4}(54) \mathrm{HCO}_{3}(36) \mathrm{Cl}(10)}{\mathrm{Ca}(45)(\mathrm{Na}+\mathrm{K})(39) \mathrm{Mg}(16)} \mathrm{pH}=7.7 \text {. }
$$

In winter, waters of above-permafrost taliks are cryogenically metamorphosed, and their mineralization increases. During the work of the RAE-S in 2019, sodium sulfate waters with salinity of about $9 \mathrm{~g} / \mathrm{L}$ were revealed. They formed an icing in the mouth of the Skardalen Valley (Fig. 1). Magnesium sulfate waters with the mineralization of $6.3 \mathrm{~g} / \mathrm{L}$ were found under the blister above the bed of the Gren River. According to the analysis of winter samples, the Grendal Lake is also characterized by sulfate composition with the mineralization of about $0.7 \mathrm{~g} / \mathrm{L}$.

The zone of hindered water exchange includes subpermafrost slightly saline sodium bicarbonate waters with the mineralization of $0.5-3.5 \mathrm{~g} / \mathrm{L}$ mainly allocated to the zones of fracturing of the Paleogene aquifer complex and partially to the upper layers of the Lower Cretaceous aquifer complex. The levels of sodium bicarbonate waters may be significantly higher than the sea level: $15-20 \mathrm{~m}$ in the settlement of Kolsbey, $25-30 \mathrm{~m}$ at the Barentsburg mine, and reaching $100 \mathrm{~m}$ above sea level or higher at the Grumant mine (Obidin, 1958). This difference in the levels of sodium bicarbonate waters at similar distances from the sea may be explained by the altitude of the catchment areas and by the different drainage of aquifers and the filtration resistance of the sea bed into which they are discharged. The submarine discharge is evidenced by a decrease in the head of these waters towards the sea.

The works of the RAE-S revealed the discharge of subpermafrost sodium bicarbonate waters in the form of springs and icings. In summer 2019, the Oin source near the Oin hydrolaccolith was characterized by sodium bicarbonate composition with the mineraliza- 
tion of $1.3 \mathrm{~g} / \mathrm{L}$. Well 9, drilled $400 \mathrm{~m}$ from the source in 2018, uncovered the ice core of the Fili hydrolacco-

lith, which was also dominated by $\mathrm{Na}^{+}$and $\mathrm{HCO}_{3}^{-}$ions (Demidov et al., 2019). A sodium bicarbonate composition with the mineralization of $0.86 \mathrm{~g} / \mathrm{L}$ is typical for waters which feed the ground ice at the mouth of the Tro Valley at its confluence with the Coles Valley. In 2020 , sources of sodium bicarbonate water with a salinity of about $1.6 \mathrm{~g} / \mathrm{L}$, forming icings, were revealed in the Rein Valley at the altitude of $36 \mathrm{~m}$ above sea level at the base of hydrolaccoliths at the foot of the Riper Mountain (Fig. 1) and at an altitude of $126 \mathrm{~m}$ above sea level at the foot of the Merkoll Mountain (to the east of the mapped area in Fig. 1). Similar sources of soda composition with the mineralization of the first units of $\mathrm{g} / \mathrm{L}$ related to hydrolaccoliths are also known in the Advent Valley, the next one north of the Coles Valley (Hodson et al., 2020). Therefore, it may be assumed that the origin of most of hydrolaccoliths within the Nordenskiold Land may be related to freezing of outflows of confined soda water.

Wells 1 and 3, drilled in the settlement of Kolsbey in 1956, discharged soda water at a rate of $0.5-1 \mathrm{~L} / \mathrm{s}$ (Kurkov and Neizvestnov, 1983). The permeability coefficient of Paleogene rocks determined by filtration tests in wells ranged from 0.2 to $6.1 \mathrm{~m}^{2} /$ day, which is significantly higher than the laboratory data on core samples. This confirms the fact that the permeability is mainly determined by zones of fracturing, endogenous in particular, because the zone of exogenous fracturing does not exceed $100 \mathrm{~m}$ and is considerably frozen.

According to data by I.V. Shkola et al (cited by (Rossiiskie..., 1998)), gases in these waters in coal exploration wells are dominated by methane (76 vol \%), the content of which increases with depth. Nitrogen may comprise up to $19 \%$, and the portion of heavy hydrocarbons may be up to $9 \%$, which is typical for areas of oil fields. The appearance of gas in wells that uncover the lower Paleogene layers (the Barentsburg formation of the Paleocene characterized by increased (up to $8-11 \%$ ) porosity) is often seen in the vicinity of the Barentsburg and Grumant mines (Verba, 2013). M.L. Verba supposes that the upper boundary of the permafrost is a cover not only for gas, but also for oil accumulations. Oil in the Paleogene deposits is found in a number of openings at the Barentsburg mine and in many core wells drilled at the Barentsburg, Kolsbey, and Lailen sites. A self-discharge of viscous oil occurred at the last site at a depth of $238 \mathrm{~m}$ under the base of the permafrost layer in well 561, drilled in sandstones of the Barentsburg formation (Verba, 2007). The $\mathrm{CO}_{2}$ content may reach 3.9\% (Obidin, 1958).

The generalized chemical composition of these waters may be described by the following formula (Kasatkin and Neizvestnov, 1983):

$$
\mathrm{CH}_{4} M_{0.5-3.3} \frac{\mathrm{HCO}_{3}(78) \mathrm{Cl}(21-22) \mathrm{SO}_{4}(0-1)}{(\mathrm{Na}+\mathrm{K})(97) \mathrm{Mg}(1-2) \mathrm{Ca}(1-2)} \mathrm{pH}=7-7.7, \quad T=2{ }^{\circ} \mathrm{C} .
$$

Another type of water in the zone of hindered water exchange includes subpermafrost saline sodium chloride waters of the marine type with the mineralization of $30-35 \mathrm{~g} / \mathrm{L}$ in fractured zones of the Lower Cretaceous deposits and waters of Paleogene deposits near the coast. Intrusions of these waters near the coast under accumulative and abrasive terraces are hydraulically related to the sea and may be an integral part of the layer with temperature below zero. According to some data (Obidin, 1958), their level at the Barentsburg and Grumant mines coincides with the sea level in Isfjorden, and an insignificant increase in the groundwater level revealed in some wells is related to the saturation of these waters with gas. This work also contains data of water-level monitoring observations in well D-4 under natural conditions and under pumping. The well was drilled at the Barentsburg mine $50 \mathrm{~m}$ from Isfjorden. The water level in the well fluctuated synchronously with the tides from the absolute level of 0 to $1 \mathrm{~m}$ (the tide height did not exceed $1.4 \mathrm{~m}$ ). With the use of a pump with the capacity of $1.5 \mathrm{~L} / \mathrm{s}$, the drop in water level in the well did not exceed $5 \mathrm{~cm}$, and the chemical composition of water after pumping was completely identical to that of seawater. Sodium chloride waters of marine genesis probably saturated all rocks in the central part of the basin to a depth of $1400 \mathrm{~m}$, i.e., to the top of the regional Jurassic aquiclude composed of clays and clay shale. These waters are immobile, and their recharge, movement, and discharge are determined by changes in the relative sea level. According to data by I.V. Shkola et al. (cited by (Rossiiskie..., 1998)), the gas composition of sodium chloride waters of the Low Cretaceous aquifer complex is characterized by approximately $74-62 \%$ of nitrogen and $24 \%$ of methane. Heavy hydrocarbons comprise up to $1.2 \%$. These data on the gas composition of the Low Cretaceous and the underlying aquifer complexes were obtained by analyzing the gases in the flush water that returned from the Grumant parametric well.

The typical generalized composition of saline waters of the Lower Cretaceous complex may be seen by the example of underground waters uncovered by well 1 in Barentsburg at depths of 200-400 m (Kurkov and Neizvestnov, 1983):

$$
M_{32.4} \frac{\mathrm{Cl}(97) \mathrm{HCO}_{3}(2) \mathrm{SO}_{4}(1)}{(\mathrm{Na}+\mathrm{K})(81) \mathrm{Mg}(13) \mathrm{Ca}(6)} .
$$


Waters of the zone of the stagnant water regime of typical sodium chloride and calcium mineralization are spread under the Jurassic aquiclude. The gas composition of underground water is mixed nitrogenmethane in rocks of the Middle and Upper Triassic and is mainly carbon dioxide in rocks of the Lower Triassic and Perm.

A specific type of groundwater-overcooled water brines (cryopegs)-occurs in the lower parts of river valleys, where thin alluvium is underlain by saline marine sediments. These sediments, which emerged from the sea level in the Holocene, were formed under temperature conditions close to modern ones. This resulted in the formation of cryopegs in them, the freezing temperature of which is in equilibrium with the modern temperature conditions. A cryopeg was uncovered by verification well 19 in spring 2020 on the EM profile laid across the Grendalen Valley (Fig. 5, section B1-B2). A sodium chloride cryopeg with a mineralization of $43 \mathrm{~g} / \mathrm{L}$ was revealed at a depth of $4 \mathrm{~m}$, which corresponds to the area with a specific electrical resistance of 2-4 Om m identified on the geoelectric section.

Karst sulfate interpermafrost waters of the Carbonic-Permian aquifer complex. Exploration wells were never drilled on the western shore of Grønfjorden. Therefore, the data on the groundwater of this area may be only obtained by studying springs, lakes, and icings. This area is assigned to the western marginal part of the West Spitsbergen cryoadartesian basin, where the Upper Permian gypsum-bearing rocks outcrop, which determines their hydrogeochemical specifics. There are four strong sulfate springs in the area of Congress Lake and icings of sulfate composition on the southern shore of the Linne Lake. The location of the sources and the lake basin may also be related to the development of karst processes in gypsum deposits.

Karst sulfate interpermafrost waters of the Carbonic-Permian aquifer complex feed the Congress-1 artesian spring (95 $\mathrm{m}$ above sea level) on the shore of the Congress Lake. Waters here are magnesium-calcium sulfate with the smell of hydrogen sulfide (Postnov, 1983):

$$
\mathrm{H}_{2} \mathrm{~S} M_{1.66} \frac{\mathrm{SO}_{4}(92) \mathrm{HCO}_{3}(7) \mathrm{Cl}(1)}{\mathrm{Ca}(71) \mathrm{Mg}(24)(\mathrm{Na}+\mathrm{K})(5)} \mathrm{pH}=7.7 .
$$

The yield of the source is $3 \mathrm{~L} / \mathrm{s}$ (with $95 \%$ probability), and the water is assigned to category $\mathrm{C} 1$. According to the conclusion of the Research Institute of Balneology and Physiotherapy, water of the source is assigned to drinking mineral water according to GOST (State Standard). It is proposed to be used in case of chronic diseases of the liver and biliary tract, metabolic diseases (diabetes mellitus, uric acid diathesis, and oxaluria), and chronic pancreatitis (Postnov, 1983). In winter, the surface runoff disappears and water of the source is redistributed to Congress Lake through the talik.
Water in Congress Lake is also magnesium-calcium sulfate with mineralization in the surface layer of $0.1-1.3 \mathrm{~g} / \mathrm{L}$. From a depth of $39 \mathrm{~m}$, it is contaminated by hydrogen sulfide. Its presence is explained by the reduction of sulfates. The low water discharge of the Congress Stream (the only surface watercourse in the studied area, which does not freeze in winter) is constant throughout its entire length and is about $180 \mathrm{~L} / \mathrm{s}$. According to data by I.Yu. Misnik and I.S. Postnov (Rossiiskie ..., 1998) and the results of the RAE-S work, the stream mineralization in summer drops to $0.1-0.4 \mathrm{~g} / \mathrm{L}$, as opposed to $0.2-2.4 \mathrm{~g} / \mathrm{L}$ in winter (the low-water period). It may be concluded that the lake is additionally recharged by the surface runoff in summer, while in winter it is only supplied by underground waters of the Carbonic-Permian aquifer complex.

The Congress- 2 source ( $86 \mathrm{~m}$ above sea level) is characterized by year-round discharge. Its mineralization is slightly lower when compared with the Congress- 1 source and is close to the mineralization of the lake. This is obviously a transit source recharged by the lake water. Hydrogen sulfide is absent here as a result of its oxidation by carbon dioxide during filtration.

According to data by I.Yu. Misnik and I.S. Postnov (Rossiiskie ..., 1998), the depth of Congress Lake is $65 \mathrm{~m}$ and the water temperature is +1.7 to $+2.2^{\circ} \mathrm{C}$. It is obvious that the lake is a talik zone. It is also discharged through the Congress- 3 and Congress- 4 sources (100 $\mathrm{m}$ above sea level), the composition of which is similar to that of the Congress- 1 source.

Recharge of fresh and slightly saline subpermafrost waters. Fresh and slightly saline waters are discharged in springs and are uncovered by wells at a depth from several tens to $100 \mathrm{~m}$ above sea level. Their composition is magnesium-calcium sulfate on the western shore of Grønfjorden and sodium bicarbonate in the rest of the area under study. The recharge of these underground waters under the conditions of the overlying layer of frozen rocks is still discussed. N.A. Zenkov concluded about the juvenile nutrition of sodium bicarbonate waters. F.T. Kashirin rejected the possibility of groundwater recharge by the infiltration of surface precipitation because of the thick permafrost layer. The scientist assigned all waters to relict, buried from the Tertiary Period (cited by (Obidin, 1958)). A.V. Kurkov and Ya.V. Neizvestnov (1983) suggested that sodium bicarbonate waters are a metamorphization product of fresh hydrocarbonate calcium waters of atmospheric origin which saturated fissured rocks of the zone of free water exchange prior to the island glaciation. The long-term presence of these waters in the rock resulted in their increased mineralization. They are dominated by more soluble sodium bicarbonate instead of calcium bicarbonates. Ya.V. Neizvestnov and A.V. Kurkov also believe that the slight water exchange is provided by the infiltration of surface water through cracks in the permafrost layer. 
Table 2. Hypsometric data on the warm ice layer in some polythermal glaciers of the research area based on the GPR data

\begin{tabular}{l|c|c|c|c}
\hline \multicolumn{1}{c|}{ Glacier } & $\begin{array}{c}\text { Minimal altitude of the } \\
\text { base, m above sea level }\end{array}$ & $\begin{array}{c}\text { Maximal altitude of the } \\
\text { top, m above sea level }\end{array}$ & $\begin{array}{c}\text { Maximal thickness } \\
\text { of the layer, m }\end{array}$ & $\begin{array}{c}\text { Minimal depth of the } \\
\text { top from the glacier } \\
\text { surface, m }\end{array}$ \\
\hline Aldegonda & 150 & 330 & 70 & 50 \\
Eastern Grønfjorden & 130 & 370 & 120 & 40 \\
Western Grønfjorden & 40 & 430 & 130 & 60 \\
Tavle & 210 & 280 & 30 & 70 \\
Fritjof & 50 & 530 & 200 & 30 \\
Erdman & 100 & 450 & 110 & 30 \\
\hline
\end{tabular}

The depth and thickness of the warm ice layer is calculated based on the mean rate for the entire deposit of $168 \mathrm{~m} / \mu \mathrm{s}$.

In the middle of the 20th century, N.I. Obidin (1958) suggested a hypothesis of subglacial recharge of sodium bicarbonate waters. To solve this problem and reveal subglacial taliks, the scientist proposed drilling specialized hydrogeological wells on glaciers in places of their maximal thickness, penetrating into the underlying rocks. This has not yet been implemented. Later, during the works of Glaciological Expedition of the Institute of Geography of the Soviet Union, twolayered glaciers were revealed in different parts of the archipelago by the GPR method certified in several wells. They are composed of cold ice in the top part and of warm ice (containing water in the liquid phase) in the deep part (Glyatsiologiya..., 1985).

The problem of subglacial groundwater supply in the studied area has been solved. In 2018-2020, specialists of the RAE-S performed a detailed georadar profiling of a number of large glaciers for searching and mapping areas with warm water-containing ice. This work was performed on glaciers of Aldegonda, Tavle, Erdman, Fritjof, and west and east Grønfjorden (Table 2). In addition to a very contrasting boundary between the glacier and the underlying rocks, the internal stratification and local heterogeneity of ice (cracks, shafts, and drainage channels) are clearly distinguished. There are areas of warm ice in all glaciers, which appear when the ice temperature rises close to $0^{\circ} \mathrm{C}$ and water inclusions are formed. These are more contrasting objects for the electromagnetic signal when compared to ice. They are seen in sections by a sharp increase in the number of intraglacial reflections, which create an intense field of scattered waves (Fig. 13). Areas of warm (water-saturated) ice are revealed in glaciers on both sides of Grønfjorden; they are up to 200-m-thick and are spread at altitudes up to $530 \mathrm{~m}$ above sea level, i.e., significantly higher than fresh and slightly saline waters, and thus may feed them. The most detailed work was performed on the Aldegonda Glacier, where the area and volume of warm ice was determined: 0.784 and $0.020 \mathrm{~km}^{3}$, respectively.

The hypothesis of the formation of fresh and slightly saline subpermafrost waters by subglacial feeding proposed by Obidin (1958) is confirmed by the data of georadiolocation and is more reasonable in comparison with other hypotheses. The hypothesis of juvenile recharge should be rejected, because it is not substantiated by actual data. For example, water temperature is not elevated, which would be expected at the upward water filtration from a deep source. Groundwater supply by filtering precipitation through cracks in mountain rocks contradicts drilling data and the presence of several-hundred-meter-thick rocks with temperatures below zero. Significant drainage of the area, submarine discharge, large pressure gradients, and relatively high rock conductivity due to fracturing and karst processes should provide high water-exchange rates. They do not correspond to the preservation of water after the area emerges from the sea and after glaciation in the Quaternary period and to the presence of water buried since the accumulation of marine sediments in the Paleogene. It should be pointed out that sulfate and bicarbonate waters are spread at altitudes reaching $100 \mathrm{~m}$ above sea level, which exceeds the maximum altitudes of marine deposits of the Quaternary period. On the East coast of Grønfjorden, groundwater may be partially supplied from the Ishjern Lake, the depth of which exceeds $20 \mathrm{~m}$, and the waterline is $239 \mathrm{~m}$ above sea level.

\section{CONCLUSIONS}

The joint analysis of data of exploratory and hydrogeological drilling performed in the Soviet period and of drilling of shallow permafrost wells and geophysical works performed in recent years as part of the RAE-S expedition research has revealed the main features of permafrost and hydrogeological conditions in the west of the Nordenskiold Land.

(1) With respect to geocryology, the area is assigned to the zone of continuous permafrost. The thickness of rocks with a temperature below zero is about $100 \mathrm{~m}$ near the coastal zone and increases to $540 \mathrm{~m}$ on watersheds. The mean annual ground temperature near the zeroamplitude depth varies from -3.6 to $-2.2^{\circ} \mathrm{C}$. Below this layer, the temperature curve in the top part of the section tends to deviate toward positive values, reflect- 

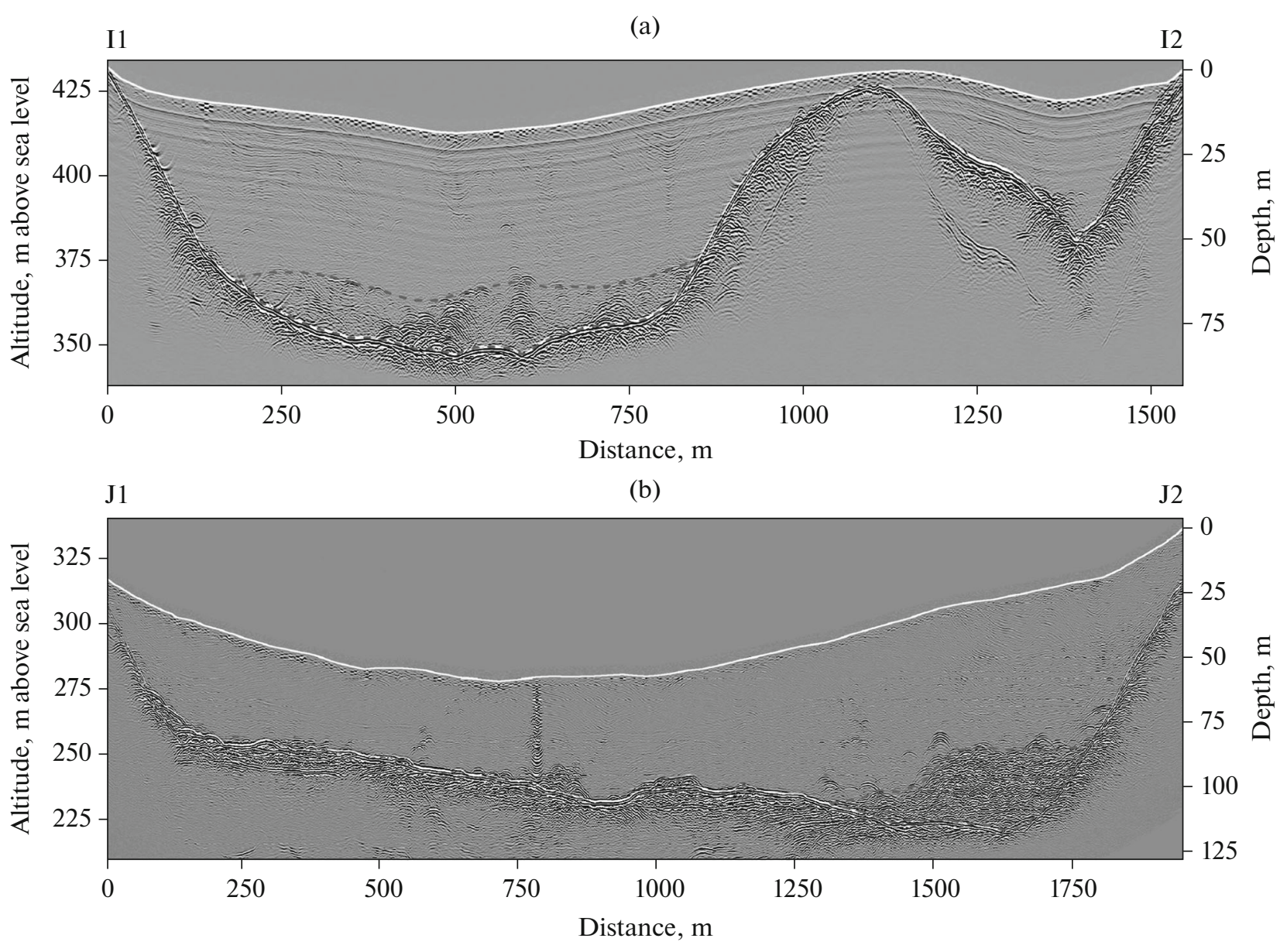

Fig. 13. GPR sections of the Tavle (a) and Aldegonda (b) glaciers.

ing the present climate-warming cycle. Continuous frozen rocks are interrupted on the shelf and in areas of glacial, under-lake, and water-thermal taliks.

(2) From the hydrogeological point of view, the area belongs to the marginal zone of the West Spitsbergen cryoadartesian basin. Seawater intrusions near the coast form saline subpermafrost aquifers of seawater composition, including those with temperatures below zero. Their depth is close to $0 \mathrm{~m}$ above sea level. Fresh and slightly saline (sodium bicarbonate on the east coast of Grønfjorden and magnesium-calcium sulfate in gypsum-bearing deposits on its west coast) subpermafrost water with hydraulic heads to $100 \mathrm{~m}$ above sea level is recharged as a result of melting of bottom layers of glaciers. Lenses of sodium chloride cryopegs were formed in the top part of the section in the lower reaches of river valleys that emerged from the sea in the Holocene. The presence of a permafrost cover contributed to a large gas content in underground water, which resulted in the formation of hydrocarbon deposits in sandstones of the Paleogene Barentsburg formation. In addition to the hydrogeochemical vertical zoning, waters in the basin are also characterized by gas zoning: the complexes, containing mainly methane, mainly nitrogen, mixed nitrogen-methane, and mainly carbon dioxide waters are changed downward.

(3) Subglacial taliks play the main role in the supply of fresh and slightly saline waters and in cryogenic processes related to them. Taliks are formed due to the presence of warm water-saturated ice in deep layers of large glaciers. Warm ice was revealed at the altitudes up to $530 \mathrm{~m}$ above sea level.

(4) Two formations are distinguished in the structure of sea terraces and mountain valleys: coarsegrained with massive cryogenic structure (the upper one) and loamy with schlieren cryogenic structure characterized by greater humidity and salinity (the deeper one). The thickness of Quaternary deposits in mountain valleys may reach $60 \mathrm{~m}$.

(5) The combination of rocky mountain ranges and vast mountain valleys composed of dispersed sediments determines the development of cryogenic geological processes and phenomena typical for both mountain (kurums, rock streams, solifluction, etc.) and lowland (heaving, frost cracking, thermokarst, etc.) areas. The presence of relatively warm permafrost, active tectonics, and glacial supply of under- 
ground water result in widely developed processes related to groundwater discharge: the formation of hydrogeogenic and near-glacier icings, blisters, and large hydrolaccoliths (pingos). In the studied area and on the Nordenskiold Land in general, hydrolaccoliths are mainly formed as a result of freezing of discharged sodium bicarbonate waters. Climate warming causes the activation of thermokarst and landslides over the STL on slopes. The beginning of landslide processes are recorded in the area of Barentsburg, and monitoring them is necessary.

At the present time, the permafrost experimental station of the Arctic and Antarctic Research Institute (AARI) in Barentsburg includes one thermometric well in rocky ground, a site for monitoring the seasonally thawing layer according to the CALM program on the sea terrace with a thermometric well, three thermometric wells on long-term heaving mounds, and three wells for monitoring taliks under river beds. The data obtained included in the international permafrost monitoring database of the GTN-P. A cable with temperature and resistance sensors is placed at the bottom of the fjord to monitor the formation of seasonal permafrost. A complex of geophysical works has been performed on the test plot. An automatic meteorological station is located there to study the processes of energy and mass exchange between the atmosphere and the surface.

The test plot makes it possible not only to research various modern permafrost phenomena in the region of Barentsburg, but also conduct a comprehensive study of the relation between permafrost-hydrogeological conditions and dynamic processes of changes in climate, sea level, and glaciation. In addition, there are data of more than century-long meteorological observations in Barentsburg, which reflect an unprecedented rate of warming. The availability of reference data on the permafrost-hydrogeological structure, including the results of numerous drilling works, makes the test plot very promising for further studying the climate effect on the cryolithosphere. Its foundation is the beginning of the creation of a uniform network for monitoring permafrost in the high-latitude Arctic along the Spitsbergen-Franz Josef Land-Severnaya Zemlya-Novosibirsk Islands-Wrangel Island transect for solving scientific and applied problems.

\section{ACKNOWLEDGMENTS}

We thank the heads of the RAE-S for organizing field works and laboratory studies at the Laboratory for Chemical Analysis in Barentsburg and to A.S. Paramzin for aerial photography.

\section{FUNDING}

This work was supported by the Russian Scientific Foundation, project no. 19-77-10066. N.E. Demidov's trip to the Alfred Wegener Institute (Potsdam, Germany) was supported by a project of the Geo-X Network. The partici- pation of S. Wetterich was supported by the German Research Society (DFG), project no. WE4390/7-1.

\section{COMPLIANCE WITH ETHICAL STANDARDS}

Conflict of interests. The authors declare that they have no conflict of interest.

\section{REFERENCES}

Akerman, J. and Boardman, J., Periglacial forms of Svalbard: a review, in Periglacial Processes and Landforms in Britain and Ireland, Cambridge, UK: Cambridge Univ. Press, 1987, pp. 9-25.

Antsiferova, A.R., Analytical review of hydrometeorological characteristics of the West Spitsbergen (as reported by Barentsburg SMO), in Sovremennoe sostoyanie prirodnoi sredy arkhipelaga Shpitsbergen (Present State of the Environment on the Spitsbergen Archipelago), Siekkinen, E.D. and Chaus, O.M., Eds., St. Petersburg: AANII, 2020, pp. 135-149.

Belousov, K.N., Tsurikova, N.M., Gradin, B.E., and Shishlov, S.B., The role of relief in the formation of the modern natural landscapes of the Spitsbergen Archipelago (on the example of the West Spitsbergen Island), Gidrogeologiya, inzhenernaya geologiya, geomorfologiya arkhipelaga Shpitsbergen (Hydrogeology, Engineering Geology, and Geomorphology of the Spitsbergen Archipelago), Neizvestnii, Ya.V. and Semevskii, D.V., Eds., Leningrad: Sevmorgeologiya, 1983, pp. 34-40.

Biskaborn, B.K., Smith, S.L., Noetzli, J., Matthes, H., Vieira, G., Streletskiy, D.A., Schoeneich, P., Romanovsky, V.E., Lewkowicz, A.G., Abramov, A., Allard, M., Boike, J., Cable, W.L., Christiansen, H.H., Delaloye, R., Diekmann, B., Drozdov, D., Etzelmüller, B., Grosse, G., Guglielmin, M., Ingeman-Nielsen, T., Isaksen, K., Ishikawa, M., Johansson, M., Johannsson, H., Joo, A., Kaverin, D., Kholodov, A., Konstantinov, P., Kröger, T., Lambiel, C., Lanckman, J.-P., Luo, D., Malkova, G., Meiklejohn, I., Moskalenko, N., Oliva, M., Phillips, M., Ramos, M., Britta, A., Sannel, K., Sergeev, D., Seybold, C., Skryabin, P., Vasiliev, A., Wu, O., Yoshikawa, K., Zheleznyak, M., and Lantuit, H., Permafrost is warming at a global scale, Nat. Commun., 2019, vol. 10, no. 1, p. 264.

https://doi.org/10.1038/s41467-018-08240-4

Blott, S.J. and Pye, K., GRADISTAT: a grain size distribution and statistics package for the analysis of unconsolidated sediments, Earth Surf. Processes Landforms, 2001, vol. 26, no. 11, pp. 1237-1248. https://doi.org/10.1002/esp.261

Brown, J., Hinkel, K.M., and Nelson, F.E., The circumpolar active layer monitoring (CALM) program: historical perspectives and initial results, Polar Geogr., 2000, vol. 24 , no. 3 , pp. $165-258$.

https://doi.org/10.1080/10889370009377698

Chernov, R.A. and Murav'ev, A.Ya., Current changes of glacier area in the western part of the Nordenskiöld Land (Spitsbergen Archipelago), Led Sneg. 2018, vol. 58, no. 4, pp. 462-472. https://doi.org/10.15356/2076-6734-2018-4-462-472

Demidov, N.E., Karaevskaya, E.S., Verkulich, S.R., Nikulina, A.L., and Savatyugin, L.M., The first results of 
permafrost observation on the cryosphere of the test site of the Russian Research Center at the Spitsbergen Archipelago (RRCSp), Probl. Arkt. Antarkt., 2016, vol. 1, no. 4 (110), pp. 67-79.

Demidov, V.E. and Demidov, N.E., Cryogenic processes and phenomena and the related hazards in the vicinity of the Russian Barentsburg mine on the Spitsbergen Archipelago, Georisk, 2019, vol. 8, no. 4, pp. 48-62.

Demidov, N., Wetterich, S., Verkulich, S., Ekaykin, A., Meyer, H., Anisimov, M., Schirrmeister, L., Demidov, V., and Hodson, A.J., Geochemical signatures of pingo ice and its origin in Grøndalen, West Spitsbergen, The Cryosphere, 2019, vol. 13, no. 11, pp. 3155-3169. https://doi.org/10.5194/tc-13-3155-2019

Førland, E.J., Hanssen-Bauer, I., and Nordli, P.Ø., Climate statistics and longterm series of temperature and precipitation at Svalbard and Jan Mayen, in Det Norske Meteorol. Inst. Klima Rep., 1997, no. 21.

Glyatsiologiya Shpitsbergena (The Glaciology of Spitsbergen), Kotlyakov, V.M., Ed., Moscow: Nauka, 1985.

Gramberg, I.S., Shkola, I.V., Bro, E.G., Shekhodanov, V.A., and Armishev, A.M., Parametric boreholes on the Barents and Kara Sea islands, Sov. Geol., 1985, no. 1, pp. 95-98.

Hodson, A.J., Nowak, A., Senger, K., Redeker, K.R., Christiansen, H.H., Jessen, S., Hornum, T.M., Betlem, P., Thornton, S.F., Turchyn, A., Olaussen, S., and Marca, A., Open system pingos as hotspots for subpermafrost methane emission in Svalbard, The Cryosphere Discus., 2020, pp. 1-21.

Humlum, O., Instanes, A., and Sollid, J.L., Permafrost in Svalbard: a review of research history, climatic background and engineering challenges, Polar Res., 2003, vol. 22, pp. 191-215.

Kasatkin, A.D. and Neizvestnov, Ya.V., Problems of water supply to the Soviet mines on the West Spitsbergen Island, in Gidrogeologiya, inzhenernaya geologiya, geomorfologiya arkhipelaga Shpitsbergen (Hydrogeology, Engineering Geology, and Geomorphology of the Spitsbergen Archipelago), Neizvestnii, Ya.V. and Semevskii, D.V., Eds., Leningrad: Sevmorgeologiya, 1983, pp. 67-82.

Koshurnikov, A.V., Demidov, N.E., Gunar, A.Yu., Zheltenkova, N.V., Krivosheya, K.V., Pogorelov, A.A., and Zykov, Yu.D., Information potential of geophysical prospecting methods in tackling geocryological problems of the land and sea shelf, Ross. Polyar. Issled., 2019, no. 2, pp. 17-22.

Krasil'shchikov, A.A., Stratigrafiya i paleotektonika dokembriya - rannego paleozoya Shpitsbergena (Stratigraphy and Paleotectonics of the Precambrian - Early Paleozoic of Spitsbergen) Sokolov, V.N., Ed., Leningrad: Nedra, 1973.

Kurkov, A.V. and Neizvestnov, Ya.V., Water-bearing systems of the Spitsbergen Archipelago, in Gidrogeologiya, inzhenernaya geologiya, geomorfologiya arkhipelaga Shpitsbergen (Hydrogeology, Engineering Geology, and Geomorphology of the Spitsbergen Archipelago), Neizvestnii, Ya.V. and Semevskii, D.V., Eds., Leningrad: Sevmorgeologiya, 1983, pp. 41-53.

Lavrent'ev, I.I., Structure and dynamics changes of the Frithiof glacier (Spitsbergen) during the past 70 years according to remote study data, Vestn. Mosk. Univ., Ser. 5: Geogr., 2008, no. 6, pp. 45-50.

Livshits, Yu.Ya., Paleogenovye otlozheniya i platformennaya struktura Shpitsbergena (Paleogen Deposits and Platform Structutre of Spitsbergen). Leningrad: Nedra, 1973.

Lotsiya Barentseva morya. Ch. I. Ostrova Shpitsbergen i ostrov Medvezhii (Sailing Directions for the Barents Sea. Pt. 1. Spitsbergen Islands and Medvezhii Island), St.-Petersburg: Gl. upr. navigatsii i okeanog. MO RF, 2001.

Matsuoka, N., Sawaguchi, S., and Yoshikawa, K., Presentday periglacial environments in Central Spitsbergen, Svalbard, Geogr. Rev. Jpn., 2004, vol. 77, no. 5, pp. 276300.

Mavlyudov, B.R., Studies of the Tavle glacier and its internal drainage canals, Nordenskiöld Land, Spitsbergen, in Kompleksnye issledovaniya prirody Shpitsbergena (Comprehensive Studies of Spitsbergen Nature), Apatity: KNTs RAN, 2007, vol. 7, pp. 187-201.

Mavlyudov, B.R., Savatyugin, L.M., and Solov'yanova, I.Yu., The reaction of Nordenskiöld Land glaciers (Spitsbergen) to climate change, Probl. Arkt. Antarkt., 2012, no. 1, pp. 67-77.

Misnik, I.Yu. and Belousov, K.N., Distinctive engineering geological conditions of the Soviet mine area on the West Spitsbergen Island, in Gidrogeologiya, inzhenernaya geologiya, geomorfologiya arkhipelaga Shpitsbergen (Hydrogeology, Engineering Geology, and Geomorphology of the Spitsbergen Archipelago), Neizvestnii, Ya.V. and Semevskii, D.V., Eds., Leningrad: Sevmorgeologiya, 1983, pp. 16-33.

Nelson, F.E., Shiklomanov, N.I., Christiansen, H.H., and Hinkel, K.M., The circumpolar-active-layer-monitoring (CALM) workshop: introduction, Permafrost Periglacial Proc., 2004, vol. 15, no. 2, pp. 99-101.

Obidin, N.I., New data on groundwater and permafrost of the Soviet mines on the Spitsbergen Island revealed by studies of 1952-1954, Tr. NIIGA, 1958, vol. 85, no. 9, pp. 129-140.

Obshchaya geokriologiya (General Geocriology), Ershov, E.D., Ed., Moscow: MGU, 2002, pt. 3, pp. 182-203.

Oledenenie Shpitsbergena (Sval'barda) (The Glaciation of Spitsbergen (Svalbard)), Troitskii, L.S., Zinger, E.M., Koryakin, V.S., et al., Moscow: Nauka, 1975.

Postnov, I.S., Mineralized waters of Spitsbergen, in Gidrogeologiya, inzhenernaya geologiya, geomorfologiya arkhipelaga Shpitsbergen (Hydrogeology, Engineering Geology, and Geomorphology of the Spitsbergen Archipelago), Neizvestnii, Ya.V. and Semevskii, D.V., Eds., Leningrad: Sevmorgeologiya, 1983, pp. 5-15.

Romanovskii, N.N., Podzemnye vody kriolitozony (Cryolithozone Groundwater), Vsevolozhskii, V.A, Eds., Moscow: MGU, 1983.

Romashova, K.V., Chernov, R.A., and Vasilevich, I.I., Studies of glacial river runoff in the Grøn-fjord Bay basin (West Spitsbergen) Probl. Arkt. Antarkt., 2019, vol. 65 , no. 1 , pp. $34-45$.

https://doi.org/10.30758/0555-2648-2019-65-1-34-45

Rossiiskie geologicheskie issledovaniya na Shpitsbergene 1962-1996 gg. (Russian Geological Research on Spitsbergen in 1962-1996), Krasil'shchikov, A.A, Ed., St. Petersburg: VNII Okeanologiya, 1998. 
Salvigsen, O. and Elgersma, A., Large-scale karst features and open taliks at Vardeborgsletta, Outer Isfjorden, Svalbard, Polar Res, 1985, vol. 3, no. 2, pp. 145-153.

Sharin, V.V., Okunev, A.S., and Lazareva, E.I., Geomorfologicheskaya karta tsentral'noi chasti ostrova Zapadnyi Shpitsbergen (Zemlya Nordenshel'da, Arkhipelag Spitsbergen) (Geomorphological Map of the Central Part of the West Spitsbergen Island (Nordenskiöld Land, Spitsbergen Archipelago)), Gusev, E.A, Ed., St. Petersburg: Renova, 2012.

Sirotkin, A.N., Marin, Yu.B., Kuznetsov, N.B., Korobova, G.A., and Romanyuk, T.V., The age of Spitsbergen basement consolidation: $\mathrm{U}-\mathrm{Pb}$ dating of detrital zircons from the Upper Precambrian and Lower Carboniferous clastic rocks of the northwestern part of Nordenskiöld Land, Dokl. Earth Sci., 2017, vol. 477, pp. 1282-1286.

https://doi.org/10.1134/S1028334X17110253

Terekhov, A.V., Tarasov, G.V., Sidorova, O.R., Demidov, V.E., Anisimov, M.A., and Verkulich, S.R., Estimate of the mass balance for the Aldegonda glacier (West Spitsbergen) in 2015-2018 based on Arctic DEM model, geodesic and glaciological data, Led Sneg. 2020, vol. 60, no. 2, pp. 192-200.

https://doi.org/10.31857/S207667342002003

Tret'yakov, M.V., Distinctive features of river runoff at the Spitsbergen Archipelago, in Geograficheskie i ekologicheskie aspekty gidrologii: Tr. Nauch. sessii, posv. 90-letiyu kafedry gidrologii sushi SPbGU, g. Sankt-Peterburg, 2627 marta $2008 \mathrm{~g}$. (Geographic and Ecologic Aspects of Hydrology. Proc. Sci. Session on the 90th Anniversary of the Chair of Land Hydrology, St. Petersburg State Univ., St. Petersburg, 26-27 March 2008), St. Petersburg: Izd-vo SPbGU, 2010, pp. 217-221.

Vasilenko, E.V., Glazovskii, A.F., Macheret, Yu.Ya., Navarro, F.Kh., Tokarev, M.Yu., Kalashnikov, A.Yu., Miroshnichenko, D.E., and Reznikov, D.S., Radiophysical studies of the Aldegonda glacier in 1999, in Materialy glyatsiologicheskikh issledovanii (Materials of Glaciological Research), 2001, no. 99, pp. 86-99.

Verba, M.L., Collector properties of the sediment shield rocks of the Spitsbergen Archipelago, Neftegaz. Geol. Teor. Prakt., 2013, vol. 8, no. 1.

Verba, M.L., Manifestations of natural hydrocarbons in the sediment shield of Spitsbergen, Neftegaz. Geol. Teor. Prakt., 2007, vol. 2.

Vtyurin, B.I., Cryogenic structure of the loose deposits of Spitsbergen, in Materialy glyatsiologicheskikh issledovanii (Materials of Glaciological Research), 1990, no. 70 , pp. 43-49.

Vtyurin, B.I., Underground ice of Spitsbergen, in Materialy glyatsiologicheskikh issledovanii (Materials of Glaciological Research), 1989, no 65, pp. 69-75.

Translated by I. Bel'chenko 